\title{
16
}

\section{Phase 6: Impact of the Sweet Potato on Swamp Landuse, Pig Rearing and Exchange Relations}

\author{
Tim Bayliss-Smith, Jack Golson and Philip Hughes
}

\section{Introduction}

\section{Is Phase 6 a separate drainage phase?}

Whereas previous phases of drainage at Kuk Swamp began after long periods of abandonment of the wetland, Phase 6 started after Phase 5 with only a brief hiatus. In the previous chapter, we reviewed evidence for the end of Phase 5 following the fall of Tibito Tephra, possibly in the AD 1660s. This event seems to have disrupted drainage and wetland gardening, but not for very long. Although dryland agriculture must have benefited from the fertilising effects of the ashfall, the wetlands were not abandoned. Within a matter of decades, Kuk Swamp was again under cultivation and into its final phase of prehistoric drainage. This last period, termed Phase 6, came to an end in the early part of the 20th century.

Golson (1977a, 1982) has seen Phase 6 as a continuation of Phase 5 in agricultural technology, but with a switch of subsistence staple to the sweet potato, Ipomoea batatas, a root crop of tropical American origin introduced by the Portuguese into the Moluccas in the early 16th century AD. In Chapter 15, section 'Reasons for disintensification', we noted Pamela Swadling's argument (1996: 155-165, 282) for the plant arriving in the Papua New Guinea highlands from the Trans-Fly region of the south coast, where, she suggests, it had been introduced between about $\mathrm{AD} 1645$ and 1790. It was pointed out that AD 1645 may only have been about 20 years before the fall of Tibito Tephra and the end of Phase 5 at Kuk.

A more recent review of the evidence has broadly confirmed Golson's earlier claims about Phase 6 (Bayliss-Smith et al. 2005), and this chapter is largely based upon that review. It would appear that Phase 6 is different from the previous phase mainly because of the effects of the transition in highlands agriculture to sweet potato. This process probably occurred about $\mathrm{AD} 1700$, with ultimately far-reaching effects upon population, surplus production, pig husbandry, social organisation and, as a side-effect, wetland landuse itself. 


\section{The Ipomoean Revolution}

There has been much debate about the environment in which the sweet potato was first adopted and whether adoption was a response to crisis or opportunity. Following Brookfield's (1989: 316-317) initial suggestion, Robinson proposed that adoption was partly a response by highlanders to extreme El Niño-Southern Oscillation events that caused severe droughts and famines around 1700 (Robinson 1999: 77-79). Others have seen the fall of Tibito Tephra, possibly in the $\mathrm{AD} 1660 \mathrm{~s}$, as a disaster that might have predisposed highlanders to sudden radical change (Modjeska 1977: 85-89). We need to begin, therefore, by setting Phase 6 within the context of highlands prehistory over the last three centuries, a period in which discussion is dominated by the so-called 'Ipomoean Revolution'.

The term 'revolution' was first used in this connection by James Watson (1965b: 305) to summarise the rapid, recent and far-reaching changes that he believed had been unleashed by the adoption of the sweet potato in the highlands. Its advantages for highlands cultivators include a shorter time between planting of its vines and harvest of its tubers, its tolerance of poorer soils and higher altitudes, its ability to sustain repeat harvests and its value as a fodder crop for pigs. Following its adoption, Watson envisaged a rapid switch from small-scale swidden agriculture based on taro to semi-permanent and intensive cultivation, as well as a transition 'from hunting and foraging to herding pigs and cultivating fodder gardens' (Watson 1977: 66). Population growth, deforestation and sociopolitical changes were related aspects of the sweet potato 'revolution' that Watson envisaged.

More recently, scholars have tried to base history upon evidence rather than speculation and they have emphasised the gradual beginnings of the Ipomoean Revolution. Polly Wiessner $(2002,2005)$, for example, has used oral histories to date the transition to sweet potato in eastern Enga as beginning nine to 12 generations prior to her fieldwork in 1985-95. If we use 25 years as the average interval between generations, her data would imply that the sweet potato first arrived between 1685 and 1760. She notes, however, that 'the sweet potato slipped into the garden regime of eastern Enga without note in historical traditions' (Wiessner 2002: 240). In Enga it was only after population growth, colonisation of the high-altitude zone and the emergence of the tee cycle of ceremonial exchange that the full social effects of the new crop were realised and its identity came to be mentioned in oral histories. Symptoms of dramatic social change occur only about four generations ago, around 1885-1915. This was the main period of agricultural intensification, when the tee cycle was expanded to finance an escalation of the Great Ceremonial Wars, which had first begun around 1825-55 (Wiessner and Tumu 1998).

In Southern Highlands Province, a similar sequence of changes has been reconstructed for the Tari region by Ballard (2001: 296). In Tari, the marginal wetlands have been used for agriculture periodically since about 2500 years ago, but the low-lying central swamps seem not to have been cultivated until long after the coming of the sweet potato. In Haeapugua Swamp, for example, the central area began to be reclaimed after the 1860s. Efforts to drain both marginal and central Haeapugua Swamp reached a peak in the 40 years or so between the 1890s and the 1930s and the reclaimed land was planted with sweet potato to produce more pigs for ceremonial exchange. In the Kopiago Basin, too, drainage of the wetland margins for sweet potato did not begin until after 1850 (Robinson 1999: 55-60). Chris Ballard argues that wetland drainage did not involve technical innovations, but there were certain social preconditions. To be successful, drainage projects required 'the organisational skill ... of male leaders to assert claims to wetland blocks, to marshal labour resources for the drainage, and to negotiate the labour of larger work groups of female relatives than is normally required in dryland production' (Ballard 2001: 299-300). 
It is interesting to note that in both Tari and Enga, the main period of agricultural intensification occurred sometime after an escalation of ceremonial exchange that had been fuelled by the sweet potato. To understand the situation in the upper Wahgi, the precise character of Phase 6 therefore needs to be critically reassessed. Was it Ipomoean in the full sense from the onset, with sweet potato cultivated in the swamp itself? Alternatively, do we see in Phase 6 merely a continuing but declining tradition of wetland landuse, still based perhaps on yam, banana, winged bean or taro? If the latter explanation is sustained, then the end of Phase 6 is the end of pre-Ipomoean wetland agriculture, which perhaps seemed obsolete and unproductive in the brave new world of dryland sweet potato production. Perhaps in the Wahgi Valley any kind of wetland landuse became problematic, because of malaria, excessive warfare or the breakdown of cooperation making wetland drainage projects less feasible.

\section{Dating Phase 6 at Kuk}

We have a clear marker for the end of Phase 5, which is signalled by the fall of Tibito Tephra, possibly in the $\mathrm{AD} 1660 \mathrm{~s}$. After this event not much time elapsed before we see evidence for renewed drainage, utilising some of the earlier network of disposal channels and field drains. These reused ditches must have been features still visible in the abandoned wetland, so that Phase 6 cannot have started more than a generation or so afterwards, probably around AD 1700. Other Phase 5 ditches, however, were relict features in the post-Tibito landscape and were not redug in Phase 6, as shown by the example in Figure 16.1.

In 1933, when Europeans came to the upper Wahgi, Kuk was uninhabited, the whole area being in a waterlogged state and covered in swamp grassland. This followed its abandonment by its customary owners, the Kawelka, as a result of their defeat in warfare, as told in oral tradition (Strathern 1972: 36-40; see Chapter 22, sections 'Histories of movement and warfare' and 'Kawelka settlement history', and Chapter 23, the first four paragraphs). The Kawelka bigman Ongka, who died in 2003 (Strathern and Stewart 2004: 166), was born in the hills of the Sepik-Wahgi Divide to the north of the upper Wahgi (Strathern and Stewart 2000b: 14 and footnote 10), where most of the Kawelka found refuge with related groups after their defeat. Since he was still a young boy when he heard the aeroplanes bringing the first white men into the upper Wahgi (Strathern and Stewart 2000b: 3), the Kawelka move from Kuk could not have predated 1933 by any great length of time and Golson suggests that it took place about 1920 (cf. Stewart and Strathern 1998: 94 with an earlier date of around 1914). Ongka was surprised by what we were finding in block A9 of the Research Station, where we started fieldwork in 1972, particularly the mounded house sites that were revealed in A9g as our workmen cut away the swamp grasses (see Figs 16.2, 17.1, 17.2). Ongka's reaction would accord with the general lack of an oral tradition of large-scale drainage among older inhabitants of the region that we report in Chapter 15, section 'The regional geography of Phase 5'. A round date of AD 1900 might be proposed for the end of Phase 6 at Kuk Swamp.

The abandonment of Kuk by the Kawelka is one example of a population movement that seems to have occurred more generally in the middle Wahgi, upper Wahgi, Nebilyer and Baiyer Valleys. As noted in Chapter 15, Paul Gorecki (1979c: 104) suggests that the movement was not so much from wetland to dryland as from valley flats to higher levels, linked to the arrival of malaria through contacts between highlanders and populations at lower altitudes where malaria is endemic (Gorecki 1979c: 104-105; cf. Nelson 1971: 206-207). Certainly, belief in swamps as an abode of evil spirits was common and only dispelled after the drainage of the upper Wahgi swamps in the late 1960s and early 1970s (Ketan 1998: 17). Gorecki (1979c: 105) thinks that the context for the interactions that led to the spread of malaria could have been 'trade'. 
A. Cross Section

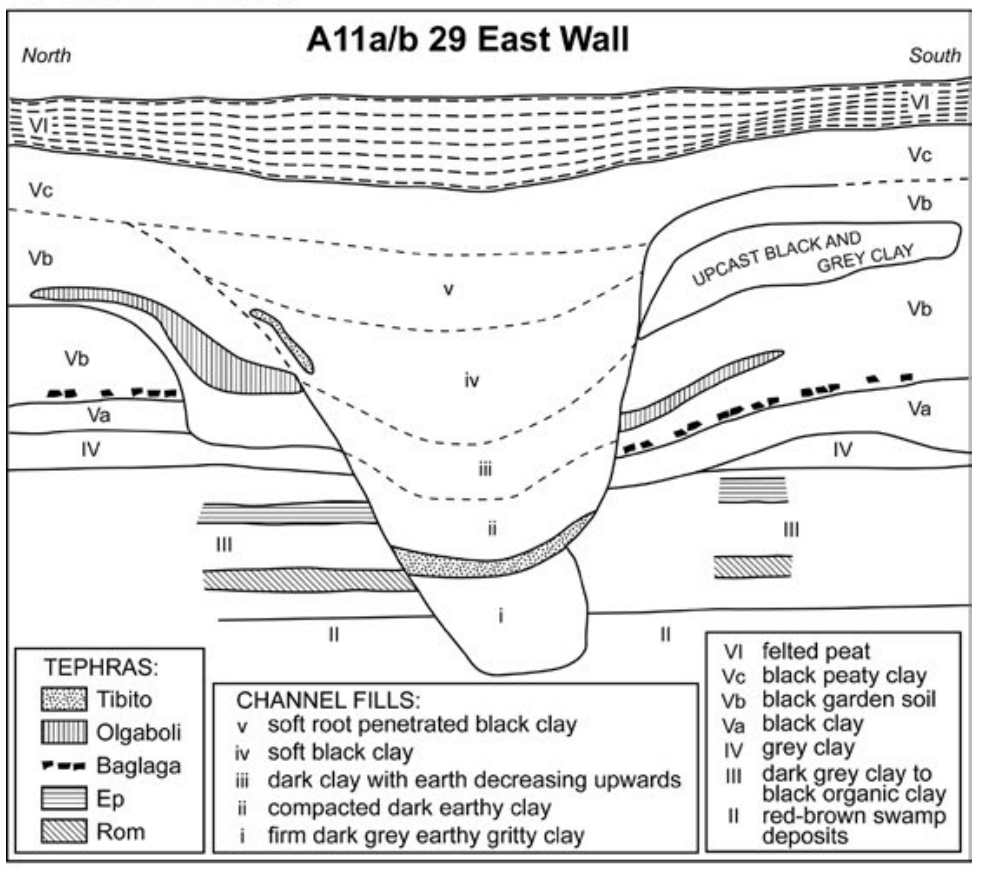

B. Interpretation

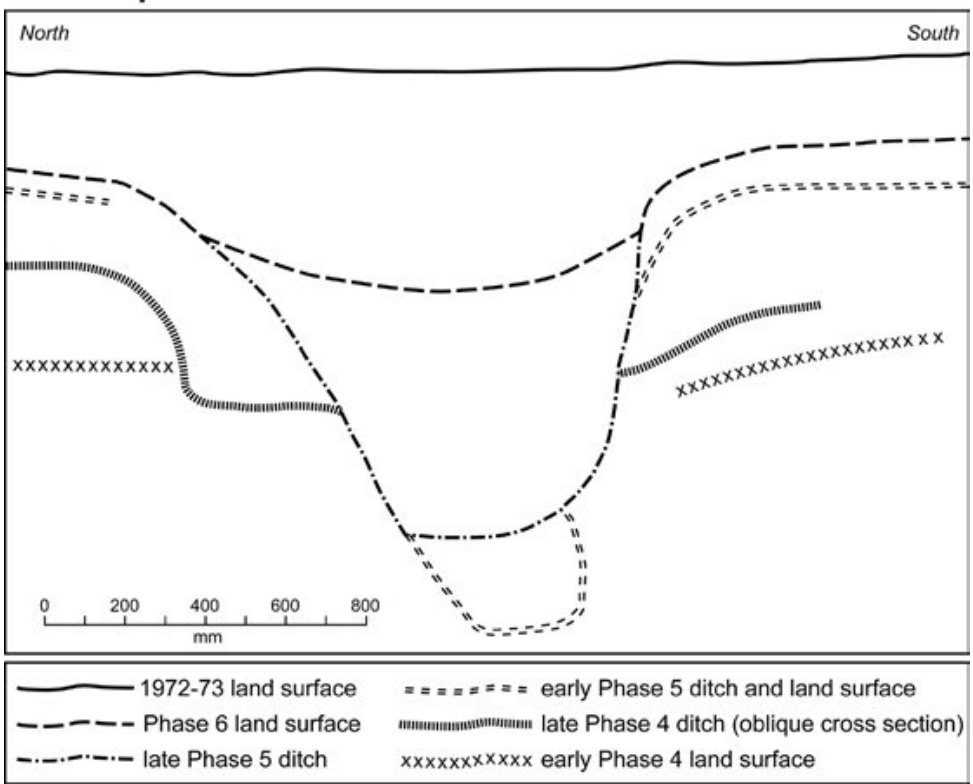

Figure 16.1 An example of a large Phase 5 field ditch in the east wall of drain A11a/b that was not reused in Phase 6.

However one interprets the evidence of the lower part of the south wall of the Phase 5 ditch-whether as it was originally dug or as the result of slumping-there seems to be little doubt about the existence of two stages to its history. The original digging cut through an earlier Phase 4 ditch, with Olgaboli Tephra in its fill, which ran somewhat obliquely across the modern drain. The spoil upcast from this activity is represented by a layer of black and grey clay thrown onto the south bank of the ditch. By the time that Phase 5 came to an end, possibly in the decade of the AD 1660s, the ditch had been redug, either immediately before the fall of Tibito Tephra, which sits at its very base, or because of a cleaning out of the new channel between its digging and the ashfall. The ditch was fully functional when the ash fell. However, as with so many Phase 5 ditches, it was not refurbished for use in Phase 6, but became a relict feature infilling through sedimentation, as shown by channel fills ii, iii and iv and by a lens of Tibito Tephra undoubtedly in secondary position close to the slanting upper wall of the structure. The ditch is an example of the disintensification of drainage that was a general feature of Phase 6.

Source: Drawing by Philip Stickler based on a 1973 field record, Kuk archive. 
It was presumably along a 'trade route' composed of braided strings of local connections that the sweet potato had made its journey to the central highlands after its entry into New Guinea at the Trans-Fly coast, as proposed by Swadling (see Chapter 15). Indeed, it can be suggested that the trade route in question was the one that brought ornaments of gold lip pearl shell (Pinctada maxima), in the form of crescents and slivers, from Torres Strait to the upper Wahgi Valley and beyond (Swadling 1994: 142-145; Swadling, Wiessner and Tumu 2008: 277) and, in the reverse direction, took the products of Wahgi and Jimi axe factories down to the Gulf of Papua (Hughes 1977: 180-181; Rhoads and Mackenzie 1991: 42-43; see Chapter 15 here). The highlands axes at the Gulf are ascribed by Rhoads to his Proto-historic Period, whose onset is 'arbitrarily' dated to about AD 1700 (Rhoads and Mackenzie 1991: 38, 40). Recent work in the region has produced a chronology that 'corresponds well' (David 2008: 469) with Rhoads and Mackenzie's Recent Ceramic and Proto-historic phases, which they start at 500 years ago and end at sustained European contact (1991: Table 1).

Swadling has pointed out (pers. comm., 2010) that trade links with the Sepik lowlands offered a closer additional or alternative source for malaria in the highlands, and indeed perhaps for sweet potato, which Wiessner (2005: 123-124) reports as arriving in western Enga from the north (cf. Ballard 2005: 9 and footnote 17). In 1932, on the lower middle Yuat, a southern tributary of the Sepik with headwaters at the Sepik-Wahgi Divide immediately north of the upper Wahgi Valley, the anthropologists Margaret Mead and Reo Fortune recorded the valuables being traded from the highlands to the Sepik plain, which included pearl shell crescents and stone axes (Swadling 2010: 149; cf. Swadling 1994: 144-145 and Swadling, Wiessner and Tumu 2008: 277). At least some of the stone axes are likely to have come from the Jimi and Wahgi quarries, judging from the distribution of known finds of such axes (undated but less than 2000 years ago, see Gorecki 1989: 169) between the highlands and the lower Sepik in what Swadling calls her lower Sepik trade sphere (2010: 150 and Fig. 8). Swadling comments that the pearl shell crescents seem to have had a greater attraction for the people of her middle Sepik trade sphere and, in considering by what route they reached there, she notes the occurrence of pearl shell crescents in the rock art of the Karawari drainage on the northern slope of the central highlands. Like the highlands axes of the lower Sepik trade sphere, the rock art is undated. However, following Swadling (2010: 150), we note the accessibility of the Karawari area, via the Yuat drainage, from the upper Wahgi Valley, where the Taylor/Leahy patrol that made the first entry into the Wahgi region in 1933 noted the best quality and greatest number of pearl shell ornaments, coming in from the south via the Nebilyer and Kaugel Valleys (cf. Swadling 1994: 143).

This trade, together with its northern extension into the Sepik observed by Mead and Fortune, clearly predates the import of pearl shell into the upper Wahgi as trade items by Europeans. Though we have envisaged the sweet potato following the shell route from the Gulf of Papua to the highlands after an introduction in the later 17th century, there is no clear indication of the shell trade representing an unbroken line of activity going any distance back in time. This seems to be a conclusion we can safely draw from the field and documentary research on trade in interior New Guinea on the eve of European contact carried out by Ian Hughes (1977) in the late 1960s on a huge, almost rectangular block of highlands and highlands fringe defined latitudinally by the Ramu River on the north and the Purari on the south and longitudinally by the upper Wahgi Valley on the west and the lower Asaro on the east. Hughes describes how in the course of his fieldwork he received from his informants a consistent story of increased movement of ornaments of marine shell in the first 30 years of the 20th century, which supplanted existing ornaments of other materials. Compared with this, the picture at the end of the 19th century appears as one in which shells were in short supply or absent (Hughes 1977: 184, 187, 198, 201). Hughes (1977: 198-201) then looks back in search of earlier patterns of shell trading as revealed by the admittedly sparse archaeological record of marine shell occurrences in his study area. 
He concludes that given the susceptibility to disruption of supplies of goods dependent on trade, particularly long-distance trade, it is likely that 'trade in sea shells was always subject to long-term interruptions and re-orientations' (Hughes 1977: 202, and see Appendix 16.1 here).

This digression on the shell trade arose out of a consideration of the mode of entry of the sweet potato into the New Guinea highlands. Going back to this question, we may note Chris Ballard's (2005: 8-9) conclusion from the literature on New Guinea terms for the two associated American plant introductions: tobacco and sweet potato. The distribution of terms is more complex for the latter than for the former, suggesting to Ballard that while tobacco followed trade routes, sweet potato 'diffused within New Guinea in a much more random manner' (2005: 9). That said, we return to Phase 6 to consider the evidence of what took place in the upper Wahgi until, at Kuk, it came to an end. The next drainage at the Kuk Swamp followed the establishment of a government Tea (later Agricultural) Research Station in 1969, initiating what we may call Kuk Phase 7 (see Chapter 23).

\section{Evidence}

In this chapter, we retain the framework used in the two previous chapters for separating evidence for Phase 6 from its interpretation. Some of the ground has already been covered in earlier discussion in Chapter 15. This is because, as indicated above, Phase 6 followed Phase 5 at no great remove in time and made use of much of the earlier infrastructure of disposal channels and to some extent of field ditches. We consider, first of all, the area of swamp that was in cultivation in Phase 6. We then review changes in the size and shape of the disposal channels, major (Wai's Baret) and minor (Simon's and Korowa's Barets), the minor ditches that served as field drains and the small fields ('plots', 'gardens' or 'raised beds') that they defined. Some of the best evidence for an Ipomoean transition comes from the swamp margins, where we see evidence for soil tillage and the formation of raised beds, possibly for sweet potato cultivation.

\section{Fences in the swamp}

Phase 6 saw the abandonment of cultivation over the greater part of the deeper swamp in the northern and eastern sections of the eastern half of the Research Station and the concentration of such activity on the swamp margins and the slightly higher ground to the south and west. Essentially, the line of the major Phase 6 disposal drain, Wai's Baret (Figs 15.2, 15.4, 16.2 and 16.3 here), marked the eastern limit of cultivation, with houses established close to it at intervals along its length. Though this was not the first appearance of houses in the swamp (correcting Bayliss-Smith et al. 2005: 118), it appears to have been the first substantial one.

In addition to what we can infer from the building of houses along Wai's Baret (see below), the evidence from Simon's Baret is particularly valuable in helping us to reconstruct Phase 6 landuse. Simon's Baret is another member of the Phase 5 drainage network (Figs 15.2 and 15.4) that reappeared in Phase 6 (Figs 16.3 and 16.4 here). However, instead of a channel flowing through drained cultivations as before, it now had cultivations only to its south and west (Fig. 15.13). Late in 1973, towards the end of the main digging season, Laurie Lucking started excavations at the western outskirts of a house that she had earlier investigated under Ron Lampert's supervision. It had been cut through by Station drain A1 $1 \mathrm{a} / \mathrm{b}$ and ended some metres east of Simon's Baret (Fig. 15.13, Phase 6 panel; see Fig. 16.3 for location). Here she found evidence of a fence line running parallel to Simon's Baret and 1-1.5 m east of it, which she traced for some $20 \mathrm{~m}$ as far as the east wall of Station drain A10/11, where Golson had recovered remains of fence posts when it had been dug earlier in the season. 


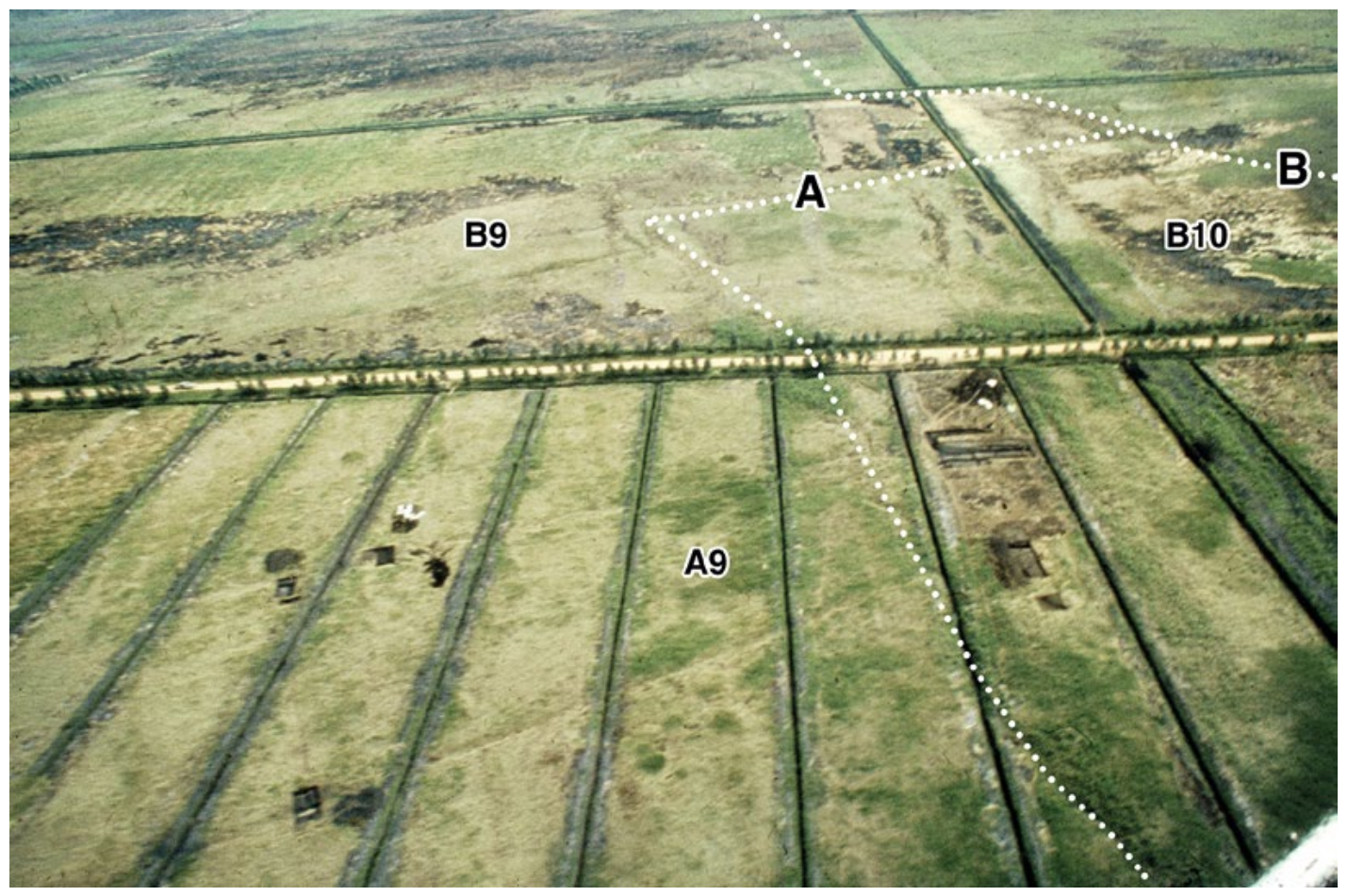

Figure 16.2 Looking north over what became in Phase 6 a frontier zone between crop planting and pig pasture.

In the southern part of the site, the frontier zone lies between Wai's (A) and Simon's (B) Barets, the former distinguished by right-angled bends, ENE in block B9 and NNW in block B10, where it is joined by Simon's Baret coming in from SSE (cf. Figs 15.2, 15.4, 15.5 and 15.6; the courses of these two drains have been digitally enhanced). West of Wai's was the tilled land, east of Simon's and Wai's lay the pasture. In between, besides some tillage, was a string of houses along the line of Wai's (see Fig. 16.3), interpreted as predominantly for women and pigs. Houses are under excavation in block A9g, one recognisable from the U-shape of the ditch defining its living area. This is House B (see Fig. 16.3 Inset), one of those presumed to be for women and pigs.

Source: Photograph by Wal Ambrose, Kuk archive, 1972.

In the 1974 season, Jim Rhoads and workmen carried out excavations for Hughes and Golson aimed at sorting out problems related to the course of drainage channels, specifically the Phase 4 channels Moni's Baret and Neringa's Baret (Fig. 14.4) and the Phases 5 and 6 channels of Simon's Baret (Figs 15.4 and 16.3), particularly in blocks A10g and A10h and blocks B10c and B10d (see the legend of Fig. 13.7 here, as well as Denham, Golson and Hughes 2004: Fig. 2). Three of the excavations associated with Simon's Baret are particularity relevant: cuttings 1 and 2 at the northern end of block A10g and cutting 25, the most northerly cutting of block B10d, just south of where Simon's Baret is crossed by Station drain B10c/d. They provided evidence of fence lines with the same characteristics of orientation and placement as the fence found by Laurie Lucking further south in 1973 as described above, that is, parallel with Simon's Baret and 1-1.5 m to its east (see Chapter 19, section 'House timbers and fence stakes'). 


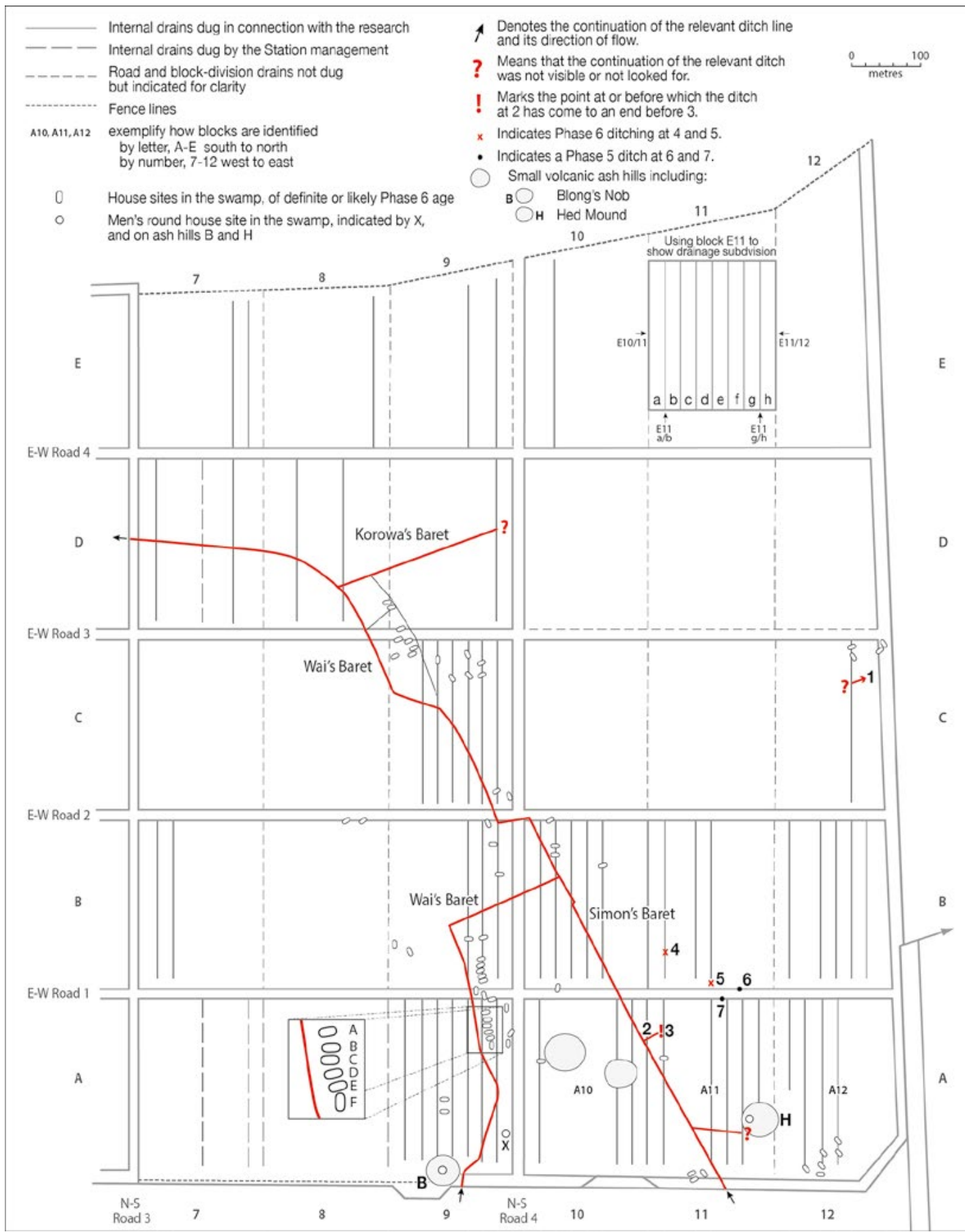

Figure 16.3 Map of the major drainage channels of Phase 6, which replicate those of Phase 5 (see Fig. 15.4).

The number and distribution of house sites reflect a major change in the use of the swamp, with cultivation largely restricted to the shallower swamp west of Wai's Baret and pig pasturage replacing it to the east. Numbers 1-7 on the map represent features of this change that are discussed, including special drainage measures to allow habitation at the margins of deeper parts of the swamp (see also Fig. 17.3 on housing).

Source: Jennifer Sheehan, CartoGIS Services, College of Asia and the Pacific, ANU. 


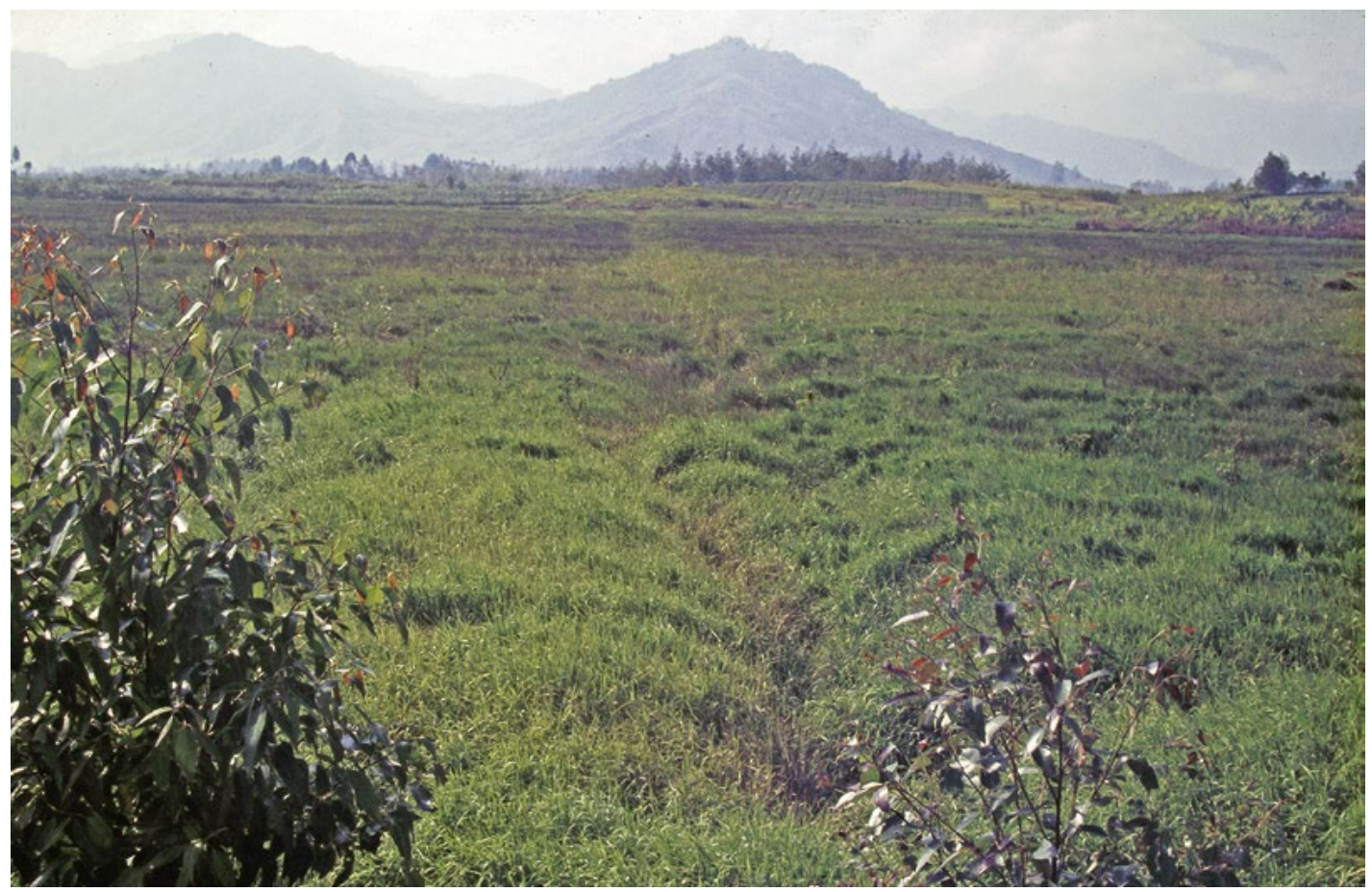

Figure 16.4 A ground view of Simon's Baret looking SSE. The western frontier of the pig pasturage of Phase 6 was marked by a fence line running parallel with Simon's Baret a metre or so to the east of it. Source: Photograph by Murray Woods, Kuk archive, 1972.

Rhoads uncovered only a limited exposure of the fence lines in question because of the size and shape of the cuttings involved. However, although the evidence was fragmentary, the implication of what was being exposed was evident. Thus:

- in cutting 2 of block A10g, immediately north of the crossing of Simon's Baret by Station drain A10/11, where Lucking's 1973 work on the fence line coming north had ceased, the fence line's continuation was exposed across the $3 \mathrm{~m}$ width of the cutting, except for a $1 \mathrm{~m}$ gap in the middle;

- as regards cutting 1 , the south wall of which is $12 \mathrm{~m}$ north of the north wall of cutting 2 measured along the line of Simon's Baret, its $2.5 \mathrm{~m}$ width is occupied by a $0.3 \mathrm{~m}$ stretch of fencing followed by a $1 \mathrm{~m}$ gap, beyond which is $0.7 \mathrm{~m}$ of fencing, then a $0.6 \mathrm{~m}$ gap to the north wall, which is $14 \mathrm{~m}$ south along the line of Simon's Baret from the south wall of the south drain of E-W Rd 1;

- concerns cutting 25 of block B10d, which starts at the north end of the kink in the course of Simon's Baret, some $154 \mathrm{~m}$ north-northwest of the south wall of the south road drain of E-W Rd 1 . The cutting is $3.4 \mathrm{~m}$ long $\mathrm{N}-\mathrm{S}$, with evidence of a $1 \mathrm{~m}$ long stretch of fencing running parallel to Simon's Baret, $1 \mathrm{~m}$ to its west, starting $2 \mathrm{~m}$ north of the south wall of the cutting and finishing $0.6 \mathrm{~m}$ south of its north wall.

There are five cases where Simon's Baret is briefly exposed on its way north-northwest to cutting 25 but where no associated fence line is recorded, the more southerly of the occurrences being $24 \mathrm{~m}$ away, the more northerly $5 \mathrm{~m}$. In these cases, however, less than a metre's width of ground was exposed east of Simon's Baret. Since a metre is the normal minimum between the drainage channel and the accompanying fence, the apparent absence of the fence line in these cuttings can readily be explained. 
From all this evidence, we soon came to accept that Simon's Baret was a combination of channel and fence, but we did not test this conclusion further in the 60 or so metres of channel between Lucking's house site on drain A11a/b and the southern boundary drain of Kuk Station. Nor did we look at the junction between Simon's Baret and Wai's, $35 \mathrm{~m}$ along the line of Simon's from the northern boundary of cutting 25 , to see what happened to fencing at and beyond this important point.

Because fences are so strongly associated today with the need to keep pigs out of areas under gardening, and since Simon's Baret has a presence in both Phases 5 and 6, it is important to establish the chronology of this particular fence line. In all the excavations by Lucking and Rhoads discussed here, with one exception, the fence lines are later than Tibito Tephra and so belong to Kuk Phase 6 . The exception is cutting 25, the most northerly of the occurrences under discussion and the only one in the B blocks. Of this Rhoads reported 'age determination uncertain' in his summary of field results (typed set of notes in the Kuk archive, 1974).

We conclude that the fence line under discussion is shown by its appearance after Tibito Tephra to mark the frontier between the gardened land of Phase 6 of which the sweet potato was part and an area of deeper swamp. Furthermore, the evidence strongly suggests that in Phase 6 this swamp was now largely converted to grazing land for pigs.

\section{Ditches in the swamp}

Ditch digging did not stop altogether in the swamp east of Simon's Baret and north of Wai's, but certainly it became much less common (for what follows in this section, Fig. 16.3 serves as a guide). In some cases, new ditches were associated with housing areas like those at the southern end of block A12 and in blocks C9 and D8 close to E-W Rd 3, as well as, to a lesser extent, in the northeast corner of block C12. The evidence comprises the house ditches themselves, but also subsidiary ditching associated no doubt with local water control, such as was mapped from surface indications at the C9/D8 housing cluster. We should note that at least the first two of these locations are at the margins of the deeper swamp. At the third location, in the northeast corner of block C12 (no. 1 on Fig. 16.3), there was a ditch dug into the fill of a late Phase 5 ditch and appearing from aerial photographs to be trending east-northeast into uninvestigated territory across the Kuk Station boundary (cf. the isolated occurrence of Phase 4 ditching in this area described in Chapter 14, section 'Fields and fallows').

There is no evidence of Phase 6 ditching in any of the Station drains of block A12 apart from that noted above for the housing area at its southern end. Three drains of block A11 - d/e, e/f and $\mathrm{f} / \mathrm{g}$-intersected the line of a Phase 6 ditch dug into the fill of a Phase 5 ditch, itself dug along the course of the Phase 3 channel that we called Kui's Baret and Denham numbered 106 (see Fig. 13.7). It seems to have run from the vicinity of Hed Mound, the site of occupation in Phase 6 (see Chapter 17, section 'Harris' excavations on Hed Mound 1977'), to join Simon's Baret. Another Phase 6 ditch almost certainly joining Simon's was dug into the fill of a Phase 5 ditch at drain A10/11 (no. 2 on Fig. 16.3). However, there is no evidence that it had been dug as far east along the line of that ditch as drain A11a/b, where Golson had recorded a composite structure (no. 3 on Fig. 16.3) with Tibito Tephra at the base of its latest phase showing this to be Phase 5. It seems likely that no. 2 was a feature belonging to the east bank of Simon's Baret, where indeed there was a Phase 6 house that we have already mentioned not far away to the southeast (Fig. 15.13). This comment about belonging to the east bank of Simon's Baret is probably also true of a case of Phase 6 ditching just to the north across E-W Rd 1, at the southern end of drain $\mathrm{B} 11 \mathrm{a} / \mathrm{b}$. Here there is a large composite ditch (no. 4 on Fig. 16.3), the latest stage of which was later than the fall of Tibito Tephra and the only example of Phase 6 digging seen anywhere along the nearly $250 \mathrm{~m}$ long drain. 
There was only one other example of a Phase 6 feature noted in the walls of the nine drains dug in blocks B11 and B12 to the east of Simon's Baret and the northern parts of the five drains in block B10, which Simon's crosses from southeast to northwest. It was found at the very southern end of drain B11d/e (no. 5 on Fig. 16.3), where a ditch had been dug on the line of an earlier ditch that had a layer of Tibito Tephra at the bottom of its infilling. There was no evidence of other Phase 6 digging with which it could be connected. It occurred quite close to a large ditch recorded by Jim Rhoads in 1973 in the south wall of the north drain of E-W Rd 1 that also had a layer of Tibito Tephra at the bottom of its fill with, however, no subsequent redigging. Rhoads gave this the identification number 2000 (no. 6 on Fig. 16.3) to anchor it in the record and his memory.

Rhoads had already recorded a similar ditch in the north wall of the south drain of E-W Rd 1 (no. 7 on Fig. 16.3) and realised that the two ditch exposures were in line with no. 3 of drain A11a/b and no. 2 of drain A10/11, both of which have been discussed above. Because of this, it was thought for a time that the alignment in question was a Phase 6 structure performing a similar function to that of the Phase 6 ditch running to Simon's Baret from the vicinity of Hed Mound (see Fig. 16.3). As we have just indicated, however, the new alignment belonged to Phase 5 and had only been reutilised in Phase 6 close to Simon's Baret.

The rarity of Phase 6 ditching in the A and B blocks east of Simon's Baret contrasts with the prominence of earlier ditching in these areas (cf. Fig. 15.13) and is likely to be equally true of the blocks to the north (see Fig. 16.5 here), where few drains were dug apart from road drains. Of course, not all the Station drains that were dug to the east of Simon's and Wai's were dug and recorded with the problems of Phase 6 ditching in mind. This is the same caveat as that we attached to our exercise in Chapter 15 using the lie of Tibito Tephra in relation to Phase 5 ditching to assess the degree of disintensification there had been during the course of the phase before it came to an end (see Chapter 15, section 'Reasons for disintensification').

Ditches continued to be maintained between Simon's and Wai's Barets, but their number decreased. Already during Phase 5 there had been a decline in drainage density, from an early level of $1740 \mathrm{~m} / \mathrm{ha}$ to $1240 \mathrm{~m} / \mathrm{ha}$ in late Phase 5 (see Chapter 15, section 'Ditch networks and field systems'). In Phase 6, this decline continued, with an average ditch density of $1090 \mathrm{~m} / \mathrm{ha}$.

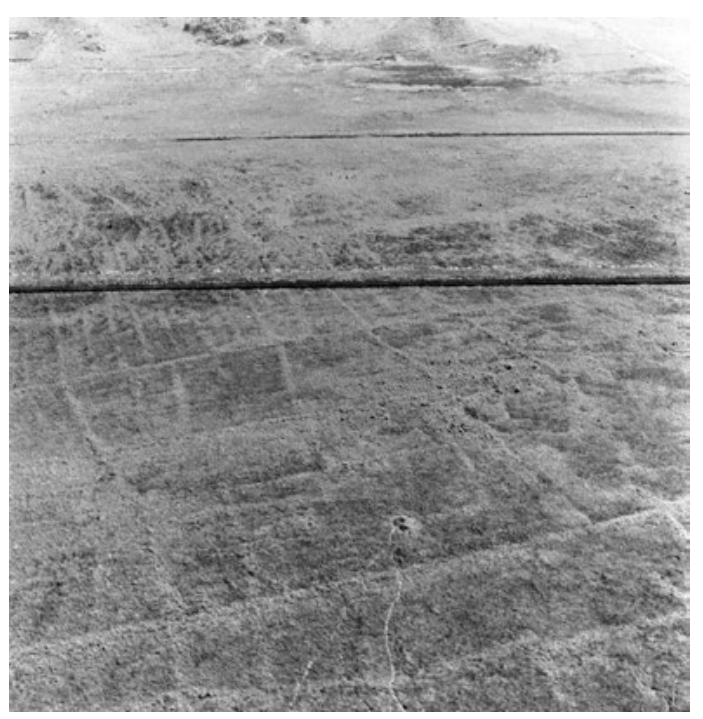

Figure 16.5 Looking north to the slopes of Ep Ridge across the fossilised evidence of Phase 5 ditches and gardens on land that became pig pasture in Phase 6.

The two lines across the swamp belong to drains for the road grid in the eastern part of Kuk Station, specifically for $E-W$ Rds 3 and 4 to the east of N-S Rd 4, View of future blocks C 10 and 11 in the bottom of the image and D10, 11 and perhaps part of 12 between the Station drains.

Source: Photograph by Wal Ambrose, Kuk archive, 1972. 


\section{The major disposal channel: Wai's Baret}

Wai's Baret, which was established at the beginning of Phase 5 and maintained throughout it, was still functioning at the onset of Phase 6 and only needed cleaning out. The need for channel maintenance must have become more pressing because of more intensive cultivation and pig rooting in the southern catchment of Kuk Swamp (Hughes, Sullivan and Yok 1991: 235). This led to an increased sediment load and the clogging up of disposal channels. Despite these growing drainage problems, the cross-sectional profiles of Wai's Baret show that the Phase 6 channel was a distinctly shallower and narrower feature than its Phase 5 predecessors (see Fig. 15.7).

The trend already established in the previous phase therefore continues, with a progressive decline in the investment needed to maintain a deep and hence efficient major disposal channel. The late Phase 5 channel had an area of about $2.0 \mathrm{~m}^{2}$ in cross-section, which already implies something like a 33 per cent decline in hydraulic capacity since the beginning of Phase 5 . The Phase 6 channel is even smaller, with an area of about $1.5 \mathrm{~m}^{2}$. This represents a further 25 per cent reduction compared with the late Phase 5 channel. In summary, by Phase 6 Wai's Baret has shrunk to only half of the capacity that it had in early Phase 5 times.

Overall, these data suggest a continued decline in the amount of labour exerted in the maintenance of the major disposal channels. It seems unlikely that the discharge carried by Wai's Baret declined between early Phase 5 and Phase 6; indeed, we have cited Hughes, Sullivan and Yok (1991: 235) for its likely increase because of accelerated runoff in the catchments promoted by increasing cultivation there. The inference must be that Wai's Baret became less efficient in evacuating water and was progressively more prone to overbank flow during high-discharge events. As argued in Chapter 15, section 'The major disposal channel: Wai's Baret', the early Phase 5 cross-section of Wai's Baret was probably effective in preventing flooding of garden lands adjacent to the channel except for the 'once in a year' large flood. Unless we invoke a decline in rainfall because of climate change, and so less runoff, we must conclude that by Phase 6 times Wai's Baret would have been progressively less efficient at preventing flooding.

\section{Minor disposal channels: Simon's and Korowa's Barets}

We see the same decline in hydraulic capacity in the minor disposal channels. For example, Simon's Baret in block A11 had a depth of only $0.9 \mathrm{~m}$ compared to $1.4 \mathrm{~m}$ for its Phase 5 predecessor (see Fig. 15.8). As well as being deeper, the earlier channel had steeper sides and was probably narrower.

The same is true of Korowa's Baret in D9 (Fig. 16.6). Here we can extrapolate ditch shapes from their surviving traces and so generate an estimate of the cross-sectional area of Korowa's Baret where the upper level, equivalent to bank-full discharge, is defined by the height of the contemporary garden soil. The channel's capacity changed as follows:

- early Phase 5: $1.7 \mathrm{~m}^{2}$

- mid-Phase 5, early: $1.8 \mathrm{~m}^{2}$

- mid-Phase 5, late: $1.7 \mathrm{~m}^{2}$

- late Phase 5: $1.5 \mathrm{~m}^{2}$

- Phase 6: $1.2 \mathrm{~m}^{2}$

Again, the Phase 6 channel is wider as well as shallower than its Phase 5 predecessors. 


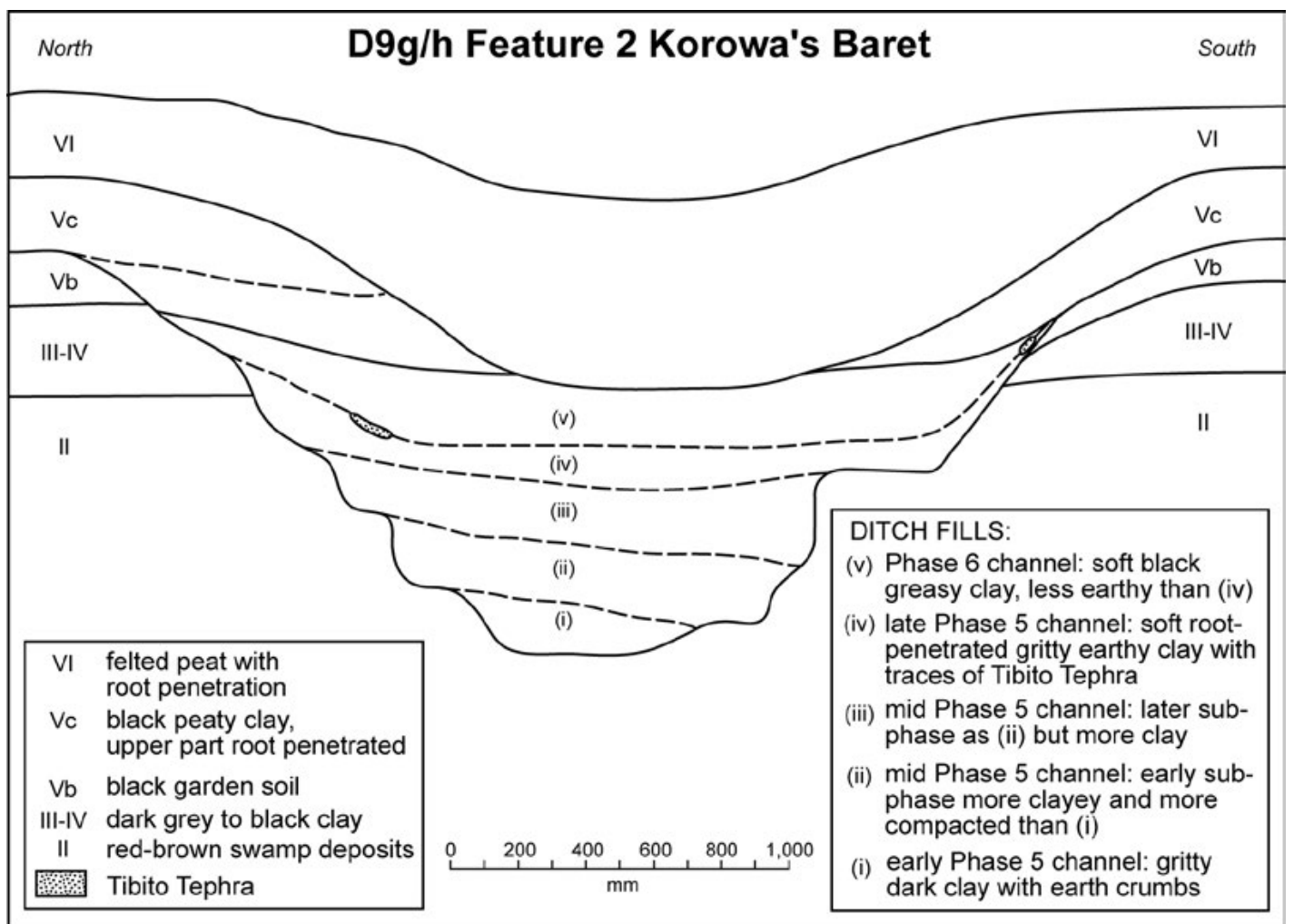

Figure 16.6 Cross-section through Korowa's Baret at drain D9g/h.

Korowa's Baret was a minor disposal channel, tributary to the major disposal channel, Wai's Baret, and draining the northeastern margins of Kuk Swamp. The stepped walls of the ditch give evidence of four subphases of construction before the fall of Tibito Tephra that marked the end of Phase 5 and there are four corresponding episodes of fill, i-iv. As with Wai's and Simon's Barets (Figs 15.7 and 15.8), the Phase 6 channel is much wider and shallower than its predecessor.

Source: Drawing by Philip Stickler based on a 1975 field record, Kuk archive.

\section{The minor field ditches}

How far are these changes in the major disposal channels mirrored in the size and shape of the field ditches that connect to them? A direct comparison can be more readily made near the southern margin of Kuk Swamp, as more Station drains were dug there and the recognition of Phase 6 ditches was easier. Thus, while six N-S drains were dug in block C9 (see Figs 15.4 and 16.3), they sampled more of the ground northeast of Wai's Baret, which was uncultivated in Phase 6 and used for housing, and less of the ground to the southwest, which was cultivated, as discussed above. The sampling adjacent to Wai's Baret in the D blocks was similarly skewed.

In contrast, block A9, which represents the swamp margins, remained in cultivation throughout Phases 5 and 6 . Here Phase 6 ditches were dug while the drainage lines of late Phase 5 were still visible, so that most of the Phase 6 network is directly superimposed on that of Phase 5 . The general shape of ditches is broadly similar (Figs 16.7 and 16.8). However, our measurements of the cross-sectional areas of samples of more than 20 ditches for each phase show that while their widths are scarcely different, in almost all cases the Phase 6 ditches were shallower features. As a result, their cross-sectional areas averaged only $0.225 \mathrm{~m}^{2}$, representing a 24 per cent decline since Phase 5 and matching the smaller size of Wai's Baret. 
A

$\mathrm{A} 9 \mathrm{~b} / \mathrm{c} 56$ West Wall
B

A10f/g 18 West Wall

Vertical/horizontal ertical/horizon
scale $(\mathrm{m})$ scale

A10f/g 14 West Wall

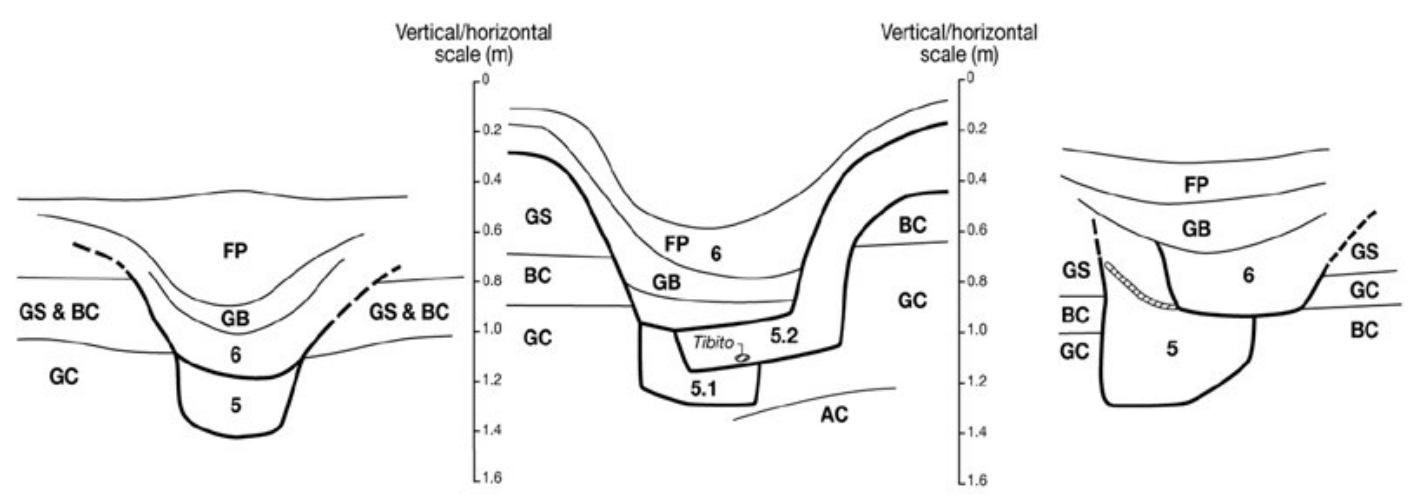

Figure 16.7 Contrasting examples of Phase 6 field ditches.

Source: Jennifer Sheehan, CartogIS Services, College of Asia and the Pacific, ANU.

The earliest stage of each ditch is deeper and narrower than anything later, as it is in the larger channels (see Figs 15.7, 15.8 and 16.6). In the case of C shown in Fig 16.7, the early structure is Phase 5 by the evidence of the Tibito Tephra lens high in its fill. In the case of B, Tibito is present in the form of a small nodule at the base of the second-stage ditch, suggesting that while the first stage is earlier than the fall of the ash, the second stage is not as decisively so, since the ash nodule could have arrived later via root activity. In the case of $\mathrm{A}$, there is nothing to prove stratigraphically that the first stage is Phase 5, but the case could be argued on grounds of its fill, which is more consolidated than that of the stage above and described as typical of young deep ditch fills. The fill below the Tibito Tephra in the earliest stage of $\mathrm{C}$ is fine and firm, while that in the two early stages of $B$ is a firm earthy clay much the same in both stages.

Turning to the later stages of each ditch, we note that B has a late Phase 6 stage with very little infill below the felted peat and the greasy black, both of which dip steeply into the ditch, leaving distinct evidence of the latter's presence in the form of a large hollow at the surface. In the case of ditch A, the primary fill dips deeply above its base and the greasy black and felted peat do the same above. In this case, however, as distinct from that of $\mathrm{B}$, felted peat has gone on to fill the hollow below and to lie level with, or indeed slightly above, the ground surface. In the case of C, the Phase 6 ditch seems to be considerably younger than the deeper Phase 5 ditch into which it is dug, by virtue of the fact that its primary fill is very root-penetrated. Because this fill is thicker than at the other two ditches, there is only a slight dip of greasy black and felted peat above it and only a faint hollow at the surface. 

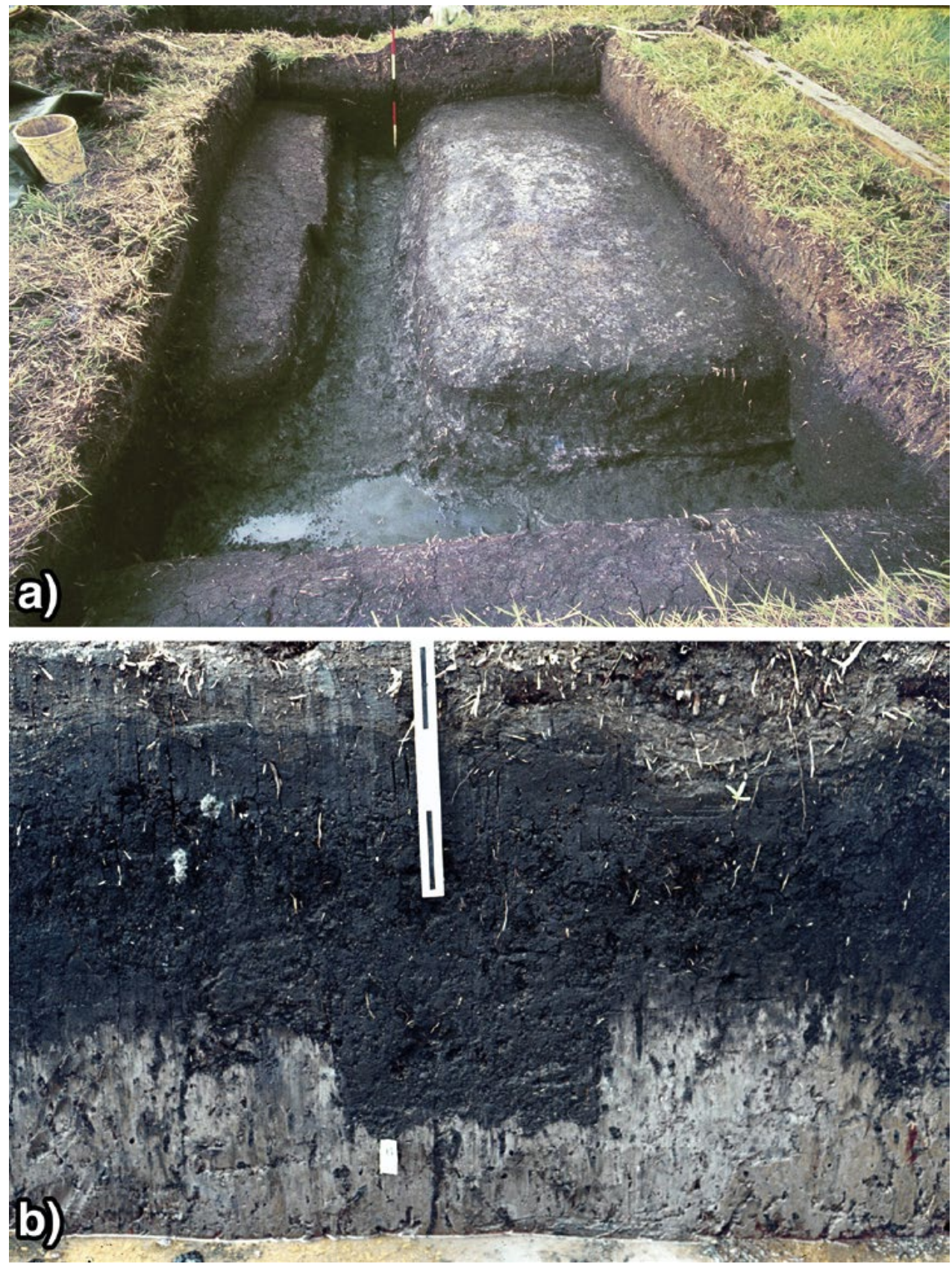

Figure 16.8 Phase 6 garden ditches.

In a) the view is SSE over Ambrose's 1972 excavation of the junction of two of the longer-lived ditches of the garden network. The site is block A9b, the second from the left of the N-S strips south of E-W Rd 1 in Figure 16.2, adjacent to the third drain from the left, $\mathrm{Agb} / \mathrm{c}$. The cross-ditch visible in the aerial view of Figure 16.2 is Baret 1 of Figure 16.12. Both ditches in a) show complex profiles from redigging. Ambrose's field record of the profile of the N-S ditch in the south wall of the excavation indicates four episodes of digging, each progressively wider and shallower than its predecessor. The fill associated with the third stage includes Tibito Tephra, meaning that only the fourth and last belongs to Phase 6 . Note the rise in the ground surface in the back wall. The ranging pole is graduated at $200 \mathrm{~mm}$ intervals. b) shows a simple ditch of the Phase 6 garden grid in the west wall of drain A9E, dug down into the top of grey clay and visible in the garden soil above it. The overlying layers of felted peat and greasy black are well developed. The scale is graduated at $100 \mathrm{~mm}$ intervals.

Source: Photographs by Wal Ambrose, Kuk archive, 1972. 


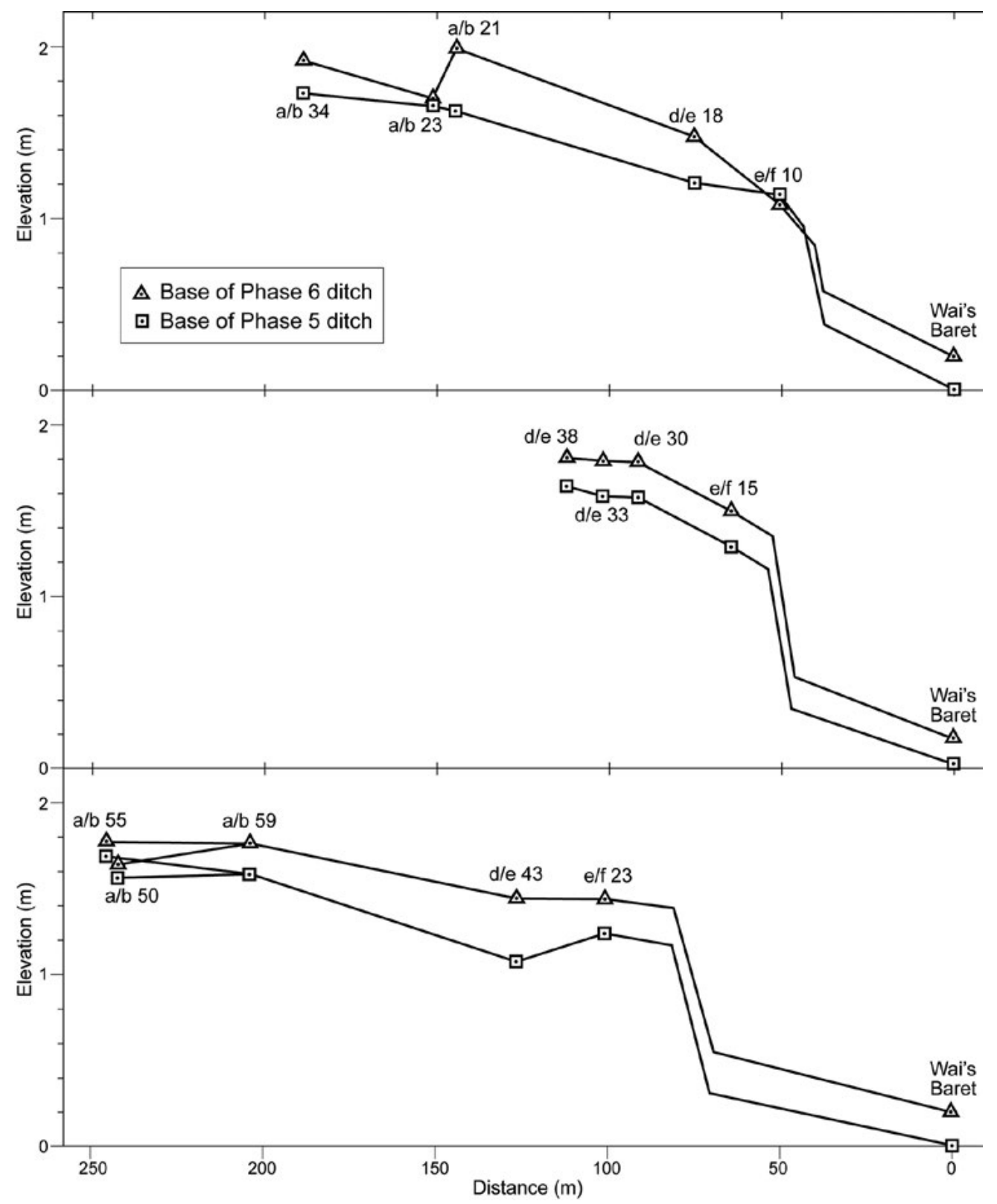

Figure 16.9 Hydraulic gradients along three lines of Phase 5 and Phase 6 drainage.

The presentation moves from minor field drains through major field drains to the major disposal channel, Wai's Baret (at Section A of Figs 15.2 and 15.7). The vertical scale has a 50x exaggeration.

Source: Drawing by lan Agnew after Bayliss-Smith et al. (2005: Fig. 3), reproduced with permission.

For the bottoms of many ditches, levelling data are available that show their elevation relative to each other as we move 'upstream' from Wai's Baret (Fig. 16.9). Apart from a few cases of overdeepening, it is clear that at all times an efficient hydraulic gradient was maintained between the fields served by the minor ditches and the major disposal channel, Wai's. In both Phases 5 and 6 , the field ditches are dug to an elevation about $1.6 \mathrm{~m}$ above the base of the disposal channel. However, although still functional in hydraulic terms, the Phase 6 network as a whole drains the land at a shallower level, about $0.2 \mathrm{~m}$ above the levels of Phase 5. As well as this shallowing of all ditches, there is the decline in cross-sectional areas, which makes it seem reasonable to describe the Phase 6 drainage network as less effective and more liable to flood hazard than the previous one. 


\section{Raised garden beds at the swamp margins}

In block A9, surface indications of the youngest ditches of the Phase 6 system were revealed by clearing away the swamp grass cover after drains had been dug across it according to the Station plan (Fig. 16.10). The evidence of these visible ditches was supplemented by a systematic search for ditches of the same age that were not visible but were discoverable by probing the surface to detect their soft fill (Fig. 16.11). Identification of ditches and their mapping was carried out by Wal Ambrose and Winifred Mumford (Fig. 16.12). Comparing the ditches recorded in profile in the walls of four Station drains cut across A9 with those mapped by Ambrose and Mumford across the blocks between them indicates that the map gives a conservative and in places an incomplete picture of the latest Phase 6 activity. Nevertheless, it provides a reasonable basis for comparisons with other drained areas and other drainage phases.

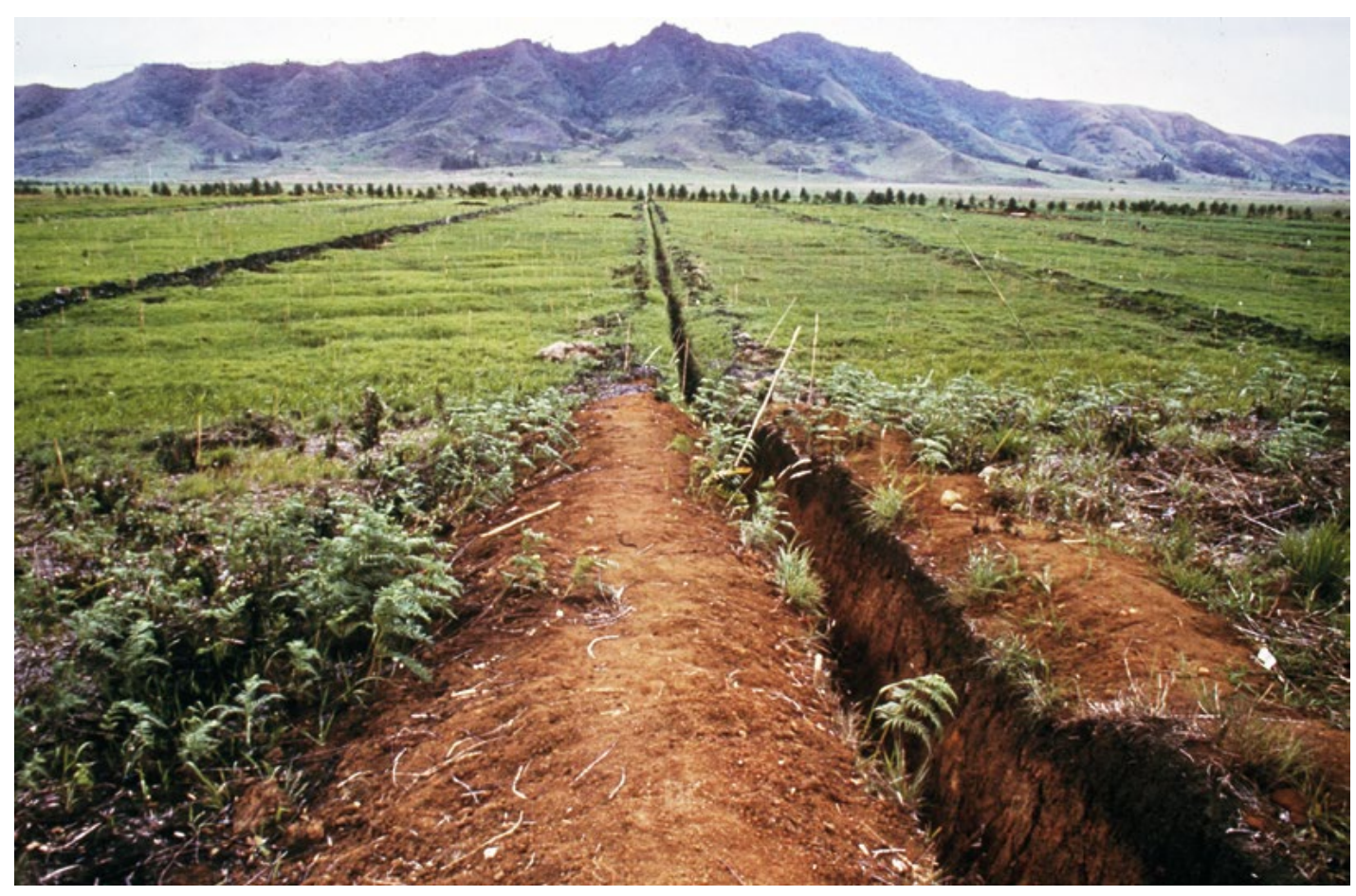

Figure 16.10 Looking north to Ep Ridge from Blong's Nob, (for location see Figure 16.3) across the surface indications of Phase 6 ditches and gardens west and east of drain $A 9 c / d$ at the centre of the image.

The linear hollows mark the course of ditches where with drainage the ditch infill and surface peat have shrunk, emphasising the built-up garden surfaces between them.

Source: Photograph by Wal Ambrose, Kuk archive, 1972. 


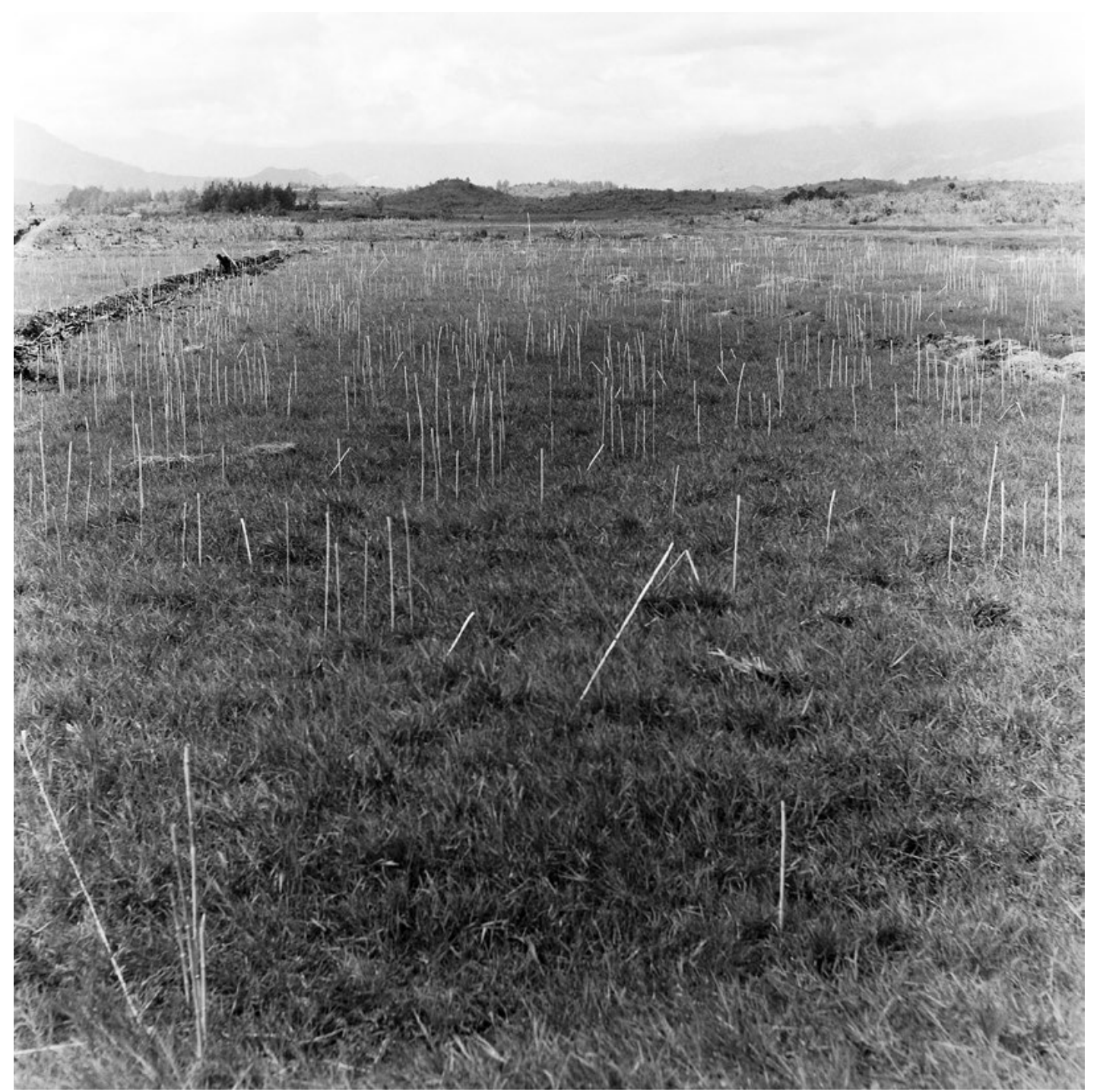

Figure 16.11 Mapping Phase 6 ditches in block A9.

Not all the ditching associated with the latest Phase 6 gardening system in block A9 was uniformly visible at the surface when Wal Ambrose and Winifred Mumford, helped by Mary-Jane Mountain, began mapping; compare ditch profile B of Figure 16.7 here with those of $A$ and $C$. The problem was to find the dips in the surface below the felted peat and greasy black that would indicate the presence of a hidden ditch belonging to the youngest network. The answer was the use of a flexible spear with a small washer at the end to sense the firmer fill below the felted peat and greasy black. When a dip was found, sticks of pitpit, saccharum spontaneum, of standard length were pushed down to mark its cross-section and single sticks to mark its course. The prodding was done at regular intervals to reveal a pattern that could then be mapped. The strips of land, looking south along block A9b, are at this stage of readiness, as indicated by the 'forest' of pitpit sticks across them, Ambrose's inspiration for the technique he employed was kauri gum digging in his native New Zealand and he had already pioneered it archaeologically there, as described by Shawcross (1976: 280).

Source: Photograph by Wal Ambrose, Kuk archive, 1972. 


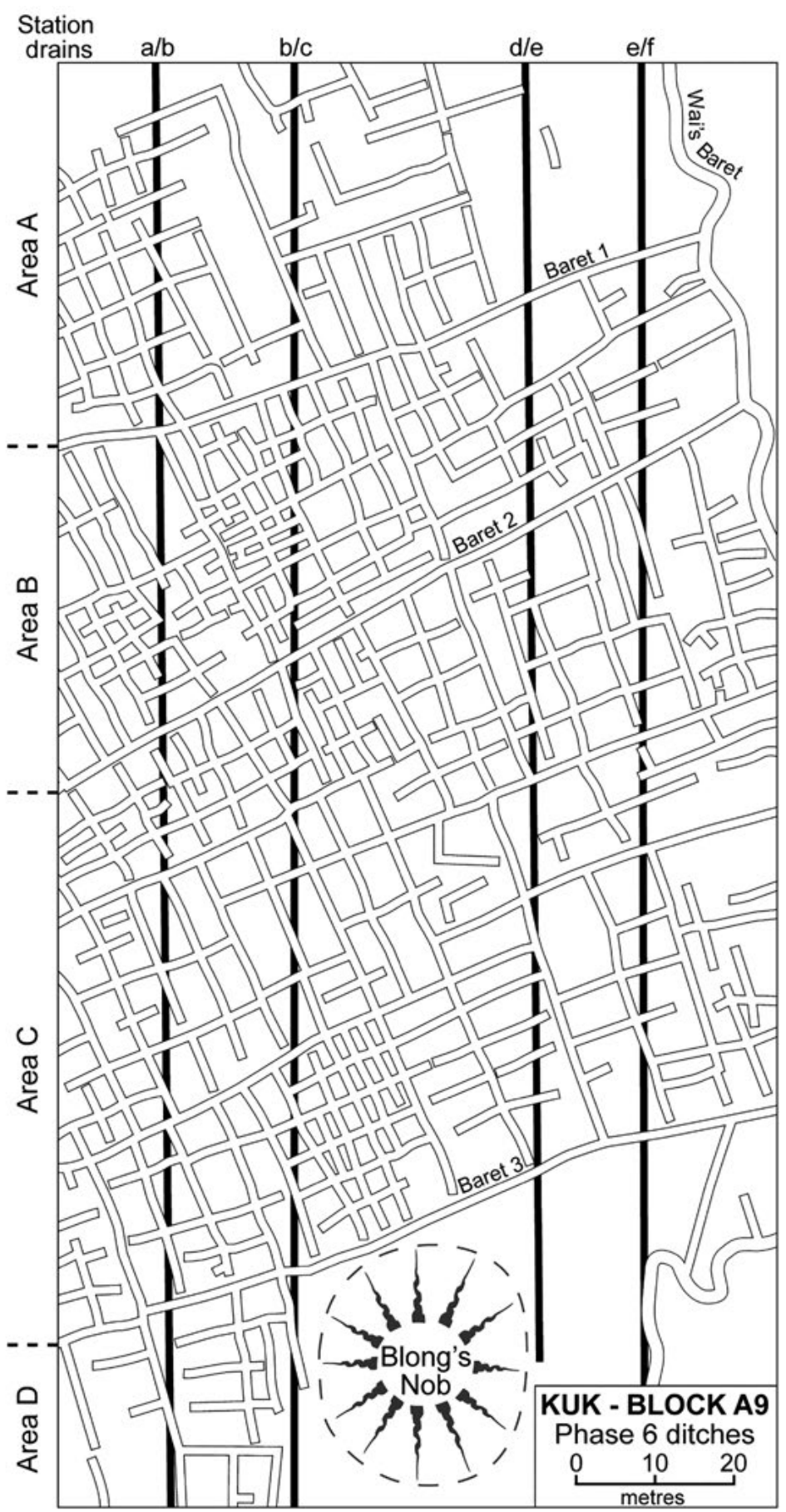

Figure 16.12 The Ambrose/Mumford map of Phase 6 ditches plotted in 1972 in block A9, as shown in Figure 16.11.

The map is based on ditches visible as surface features after vegetation clearance and partial drainage and on non-visible segments of the network found by prodding the surface to locate their fill. The appearance of the ditches in the walls of the drains that were dug across them was another source of evidence. The four drains of importance in this respect are shown on the map. A fifth drain, A9c/d, was dug but because of problems with wall collapse it could not be used to record ditch crossings in the drain walls. As a result, it is not shown on the map, though it is prominent in photographs, e.g. Figure 16.10, where it is the central feature.

Source: Drawing by lan Agnew, after Bayliss-Smith et al. (2005: Fig. 6) (reproduced with permission) and based on a 1972 field map by Wal Ambrose and Winifred Mumford in the Kuk archive. 
The map shows a higher density of Phase 6 ditches in A9 $(1880 \mathrm{~m} / \mathrm{ha})$ than existed at lower elevations in blocks A10 and 11 at this time $(1090 \mathrm{~m} / \mathrm{ha})$. As in Phase 5, the spoil served to raise the garden bed (see Fig. 16.8a). In addition, there is clear evidence that people were using other local sources of soil for the construction of raised beds. The evidence comes from three parts of the mapped area: Area A north of Baret 1, Area C north of Baret 3 and Area D south of Baret 3 (see Fig. 16.12). In all three areas, we see an increased thickness of the stratum of garden soil compared with Area B between Barets 1 and 2 and the replacement of the felted peat of Area B, which is the normal post-abandonment cover of the swamp, by a thinner root mat signifying an elevated land surface. Some of these observations would be relevant to the situation depicted in Figure 16.8a, which is at the place where the higher surface of Area A gives way to the lower surface of Area B.

The $100-150 \mathrm{~mm}$ of added material in Area A, which in places is visually differentiated in the stratigraphy, most probably came from sediments building up in Wai's Baret. It was perhaps the later dispersal of this added soil that obscured the ditches close to Wai's, which therefore were not mapped in 1972. About the same amount of added material in Area C, not stratigraphically visible, may have come from Baret 3 and/or the clays of Blong's Nob. Material from the same source(s), visible in the stratigraphy, raised the ground surface immediately south of Baret 3 in Area $\mathrm{D}$ to a level $150-340 \mathrm{~mm}$ above the surface elevation immediately to the north.

\section{Interpretation}

\section{An overview of the evidence}

Except at the swamp margins, the evidence suggests that in most parts of Kuk Swamp the transition from Phase 5 to Phase 6 involved some disintensification of landuse. Not only was the major disposal channel, Wai's Baret, in a state of relative neglect, but also other parts of the previous drainage network had fallen into disuse or were being dug on a smaller scale. The deep swamp was turned over to pig grazing, while intermediate areas saw a decline in drainage effort and the associated development of areas of housing. Judging from the area sampled in block A9, only at the swamp margins were the Kuk cultivators still producing a high density of field ditches, although almost all the ditches were shallower than in Phase 5, requiring on average about 25 per cent less spoil to be removed. Along these margins, using the ditch spoil and other material derived from Wai's Baret, raised beds were constructed similar to the ones that had been used in Phase 5, and similar also to the beds cultivated in modern times for the sweet potato.

The amount of runoff entering Kuk Swamp in Phase 6 is unlikely to have diminished; indeed a more likely scenario is one of increased flooding following the spread of sweet potato cultivation in the southern catchments. Yet the changes in ditch morphology suggest that the ditch systems of Kuk were less able to deal with the incoming runoff. At the swamp margins, we see evidence for a substantial effort to raise the level of beds in order to maintain productive landuse, perhaps avoiding intermittent flooding. The general impression is that the major disposal channels were being somewhat neglected, as dryland sweet potato gardens became a more important component in the overall landuse system.

We suggest that the declining efficiency of Wai's Baret, as of the minor disposal channels Simon's and Korowa's Barets, resulted from the increasing importance of the dryland sphere of agriculture and its products. According to this scenario, in Phase 6 times Wahgi society became more and more focused on the sweet potato, pig husbandry and regional exchange-which was indeed the situation that existed in 1933, at the very end of prehistory-and less and less able 
or willing to invest labour in the maintenance of the major disposal channels. Perhaps, because wetland production was becoming obsolete, the increased crop losses due to flooding became more acceptable.

The construction of raised gardens near the swamp margin investigated in block A9 is another likely response to the deterioration of drainage in the swamp, due to more frequent flooding because of the smaller capacity of Wai's Baret. An alternative possibility is that the employment of raised-bed technology obviated the need for deep disposal channels. In either case, we see evidence for a continued agricultural role for the swamp margins, even in the era of the sweet potato. We cannot be sure if the sweet potato itself was being grown in block A9 at this time. Given the use of raised beds at Kuk during Phase 5, we cannot regard raised beds in themselves as conclusive evidence for the sweet potato's presence, but the balance of probability surely favours the new crop.

This is certainly the assumption that was made by our workmen, and accepted by us, when charred fragments of tubers were excavated at Phase 6 house sites in 1972 and published as sweet potato (Golson 1982: 132). They included a substantial piece of the end of a tuber (Fig. 16.13), which was subsequently identified by Jon Hather (pers. comm., -2000), then of the Institute of Archaeology, University College London, as Dioscorea esculenta, the lesser yam.

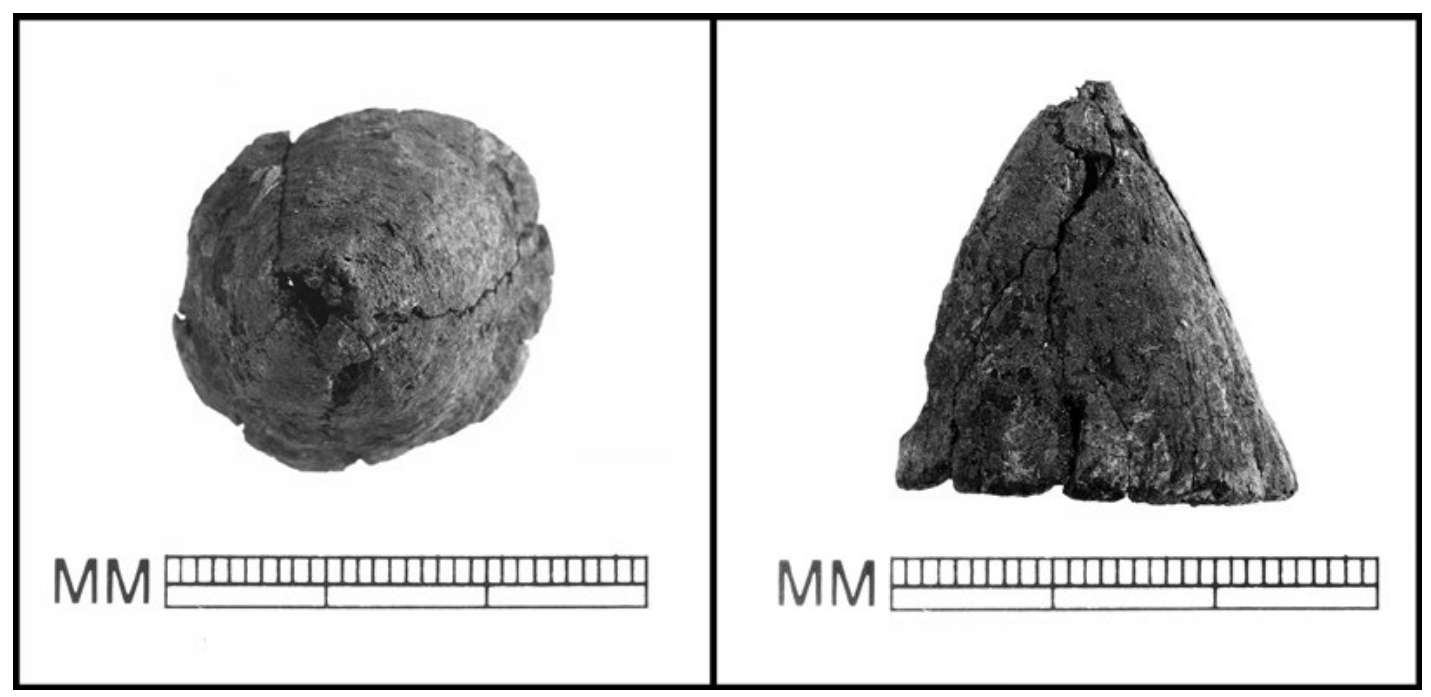

Figure 16.13 The charred end of a tuber excavated from a hearth in the front part of House B at Kuk (see Fig. 16.3 Inset and Fig. 17.5).

At left is the point of the tuber, at right is the point in profile. On discovery workers pronounced the piece to be part of a sweet potato and this was accepted by us outsiders as being the case. It was illustrated as such by Pamela Swadling (1981: 49) in her booklet on Papua New Guinea prehistory. Some 20 years later, it was identified as lesser yam (Dioscorea esculenta) by Jon Hather.

Source: Photographs by Bob Cooper and Darren Boyd.

\section{Changing gender relations}

The substantial appearance of houses in the swamp in Phase 6 is itself significant, as is the type of house that is found (see Chapter 17). The internal features of these houses match those observed by ethnographers in recent times and strongly suggest they were women's houses with space for pigs. Ethnographic analogy would point to the dispersed settlement pattern and the gendered division of labour that characterised the societies cultivating the sweet potato in the upper Wahgi in the 1930s (Vicedom and Tichner 1943-48: 143-145, 168-171; 1983: 159-161, 188-193). In the Mount Hagen area, since women had responsibility for daily sweet potato harvesting and pig husbandry, 
it was convenient for them to live near gardening and grazing areas (Strathern 1972: 54-60). In Kuk Swamp, the evidence strongly suggests an economy of sweet potato cultivation and pig grazing under women's management, within social space where women were important.

\section{Emerging big-men and pig exchange}

Although some men's houses were located not far away (see Fig. 16.3; cf. Fig. 17.3), perhaps the main focus of men's activities in Phase 6 was outside the swamp. We have already noted how ineffective were the efforts, presumably by men, to maintain Wai's Baret as a major disposal channel. By extrapolating from the reconstructed history of Enga (Wiessner and Tumu 1998; Wiessner 2002, 2005), we can suggest that by the 19th century most production at Kuk was coming from sweet potato gardens that were located in the dryland sphere. The social impact of this landuse change has been much debated.

Golson (1982: 130-135; cf. Golson and Gardner 1990: 407-408) proposed that the introduction of the sweet potato around AD 1700 initially served to 'democratise' access to wealth, especially wealth in the form of pigs foddered on surplus root crops. Previously, surplus root crop production supporting pig husbandry had been the preserve of a few privileged communities that had access to drained wetlands. After the sweet potato's potential to produce pig fodder on dryland sites had been demonstrated, even in grassland areas and at high altitude, the capacity to generate wealth became more widespread. In these circumstances, Golson suggested, big-men began to focus their attention on wealth items like pearl shell that were objects of genuine scarcity. It was an argument by analogy with the situation created by the arrival of Europeans in the upper Wahgi in the 1930s. Their possession of large quantities of previously scarce shells as payment for goods and services (Hughes 1978) threatened the exclusiveness of the regional system of ceremonial exchange (moka), whereby wealthy families monopolised pearl shell valuables and circulated them only amongst themselves.

An alternative model would emphasise a general escalation of exchange and the growing importance of large-scale pig production. Although direct evidence is lacking, we can envisage an escalation in the scale of moka activity during Phase 6 that parallels the growth of tee in Enga. Feil (1987: 263-268) has argued that moka and tee had an interrelated past, but that moka was the original institution. In the upper Wahgi Valley, participation in moka was organised under big-man leadership and was fuelled by the regional surplus of pigs. Perhaps we can find an ultimate explanation for swamp abandonment at Kuk in the competition for power that emerged between big-men and their rivals: 'potential antagonisms at most structural levels of the society ... produced conditions inimical to the sustained operation of drainage systems' (Golson and Gardner 1990: 407).

Chris Ballard's ethnographic observations from Haeapugua in Southern Highlands Province confirm that ditching and garden projects alike fail principally through weaknesses of political coordination (Ballard 2001). The relative inefficiency of the Phase 6 disposal channels at Kuk could therefore reflect an extended period of political instability in the upper Wahgi Valley. Perhaps individual leaders found it increasingly difficult to assemble and coordinate labour, both male and female, on the scale necessary to sustain large-scale wetland gardens. In the 19th century, this unstable Ipomoean world culminated in the widespread abandonment of wetlands in the upper Wahgi, as escalating ceremonial exchange, warfare and perhaps epidemics undermined the fragile bond between big-men and their factions and diverted people's agricultural efforts in other directions. 


\section{Different histories for different regions}

We should not expect this model necessarily to apply to other parts of the highlands. Each region has its own social history and particular landuse opportunities. In the upper Wahgi Valley, for example, large-scale wetland drainage, agricultural intensification and expanded exchange opportunities were already happening in Phase 4, 2000 years ago (Golson and Gardner 1990; Bayliss-Smith and Golson 1992a, 1992b, 1999; Chapter 14 here, section 'Kuk as a Phase 4 "hotspot"?'). Elsewhere, these features did not emerge until more recent times or not at all and exchange activity took different forms.

Wiessner (2002) has pointed out that in Enga it was the pig-previously circulated only for local feasts in the form of meat - that became the particular item of wealth that was targeted in Ipomoean times. The sweet potato's tolerance of marginal soils and higher altitudes encouraged population migrations that began to destabilise former intergroup relationships. In response, certain groups intensified the exchange relations that involved the movement of pigs over long distances and it was these expanded networks that evolved into the tee cycle.

To move pigs over long distances implies that the animals must be kept alive and therefore they will become troublesome if they are not fully tamed. The need for larger numbers of tame pigs requires a form of full domestication in which all stages of the pig's life cycle are regulated (Kelly 1988). In this new regime, piglets would be foddered from an early age by their owners, normally married women, making possible their easy transfer to new owners once the animals reached maturity. Among the Etolo, living on the fringes of the Southern Highlands, the piglets are kept with people day and night and are pampered and foddered for about six weeks before they become fully bonded. The young pigs can then be allowed to feed themselves in abandoned (but still fenced) sweet potato gardens, and when mature they can be traded (Dwyer 1990: 57-58). With adoption of the sweet potato, larger and more permanent settlements can be established, the forests are cleared and game animals become scarce (Dwyer 1990: 186). For the Etolo, these can all be seen as consequences of the transition from taro, yams and sago towards sweet potato as the main staple.

In Enga, a more intensive form of root crop production, a gendered division of labour and a distinctive settlement pattern are among the predicted consequences of the new pig husbandry (Wiessner 2002, 2005). If we transpose this model from Enga to Wahgi Valley, then any archaeological evidence for intensified root crop production and full pig domestication might signal similar changes in Wahgi society in the Ipomoean period, culminating in the ethnographically documented moka cycle. However, the chronology of such changes might well be different in the two areas, as the upper Wahgi Valley has a much longer prehistory of deforestation, agricultural intensification and regional exchange. John Burton (1984: 227-228), for example, shows how regional systems of trade, as inferred from the wide distribution of axes of high-quality stone from a few localised quarries, developed in the period between about 2500 and 1200 years ago. As Burton says (1984: 248), this can broadly be correlated with Phase 4 of drainage intensification at Kuk (cf. Chapter 14, section 'Kuk as a Phase 4 "hotspot"?', and Chapter 21, section 'The age of the axe trade in the upper Wahgi'). In contrast, in parts of Enga 250 years ago there was still a dependence on mixed swiddens, hunting and foraging (Wiessner and Tumu 1998: 56-66). Moreover, in the Wahgi the extensive dryland terraces, lower hill slopes and foothills represent a large and accessible land resource suitable for sweet potato, whereas in Enga a large expansion in the cultivated area had to await a colonisation of the highaltitude zone. 
In the Wahgi, we might therefore expect to see an early and widespread abandonment of wetlands in the Ipomoean period. There are indeed indications that this happened, not just at Kuk but more widely, given the absence of evidence for post-Tibito drainage from the admittedly limited investigations at Warrawau Tea Estate, to the west at Minjigina on the slopes of Mt Hagen and down the valley to the east at Kotna and at the Kana site near Minj (Golson 1977a: 628; 1982: 121; Muke and Mandui 2003; cf. Chapter 15, section 'The regional geography of Phase 5'). The widespread patterns of former drainage that are visible from the air may represent very largely pre-sweet potato cultivation, i.e. Phase 5 in Kuk terms (e.g. in the North Wahgi Swamp as shown in Fig. 16.14).

We have already pointed out in Chapter 15, such a situation would explain the lack of an oral tradition of large-scale drainage among the older inhabitants of the Mount Hagen region questioned on the matter in 1972-73 by Ian Hughes (pers. comm., cited by Golson 1977a: 628). As noted earlier, the oral histories suggest that there were widespread population movements in the recent past, connected to warfare and perhaps also to the spread of malaria into the upper Wahgi Valley (see also Chapter 22, sections 'Histories of movement and warfare' and 'Kawelka settlement history'). In the process, localities like Kuk Swamp became deserted and new concentrations of population emerged on the volcanic apron of Mt Hagen and the slopes of the volcano itself to the west, areas where Strathern (1971: 15-19) notes the largest upper Wahgi tribes as now living (Fig. 16.15). He also points to the vast range, from 68 to 6749, in the populations of the recognised 'big name' tribes of the region and underlines the need to take diachronic processes into account when considering questions of group structure. We have indicated a number of potentially relevant factors in the upper Wahgi case: sweet potato, malaria and the demise of wetland cultivation.
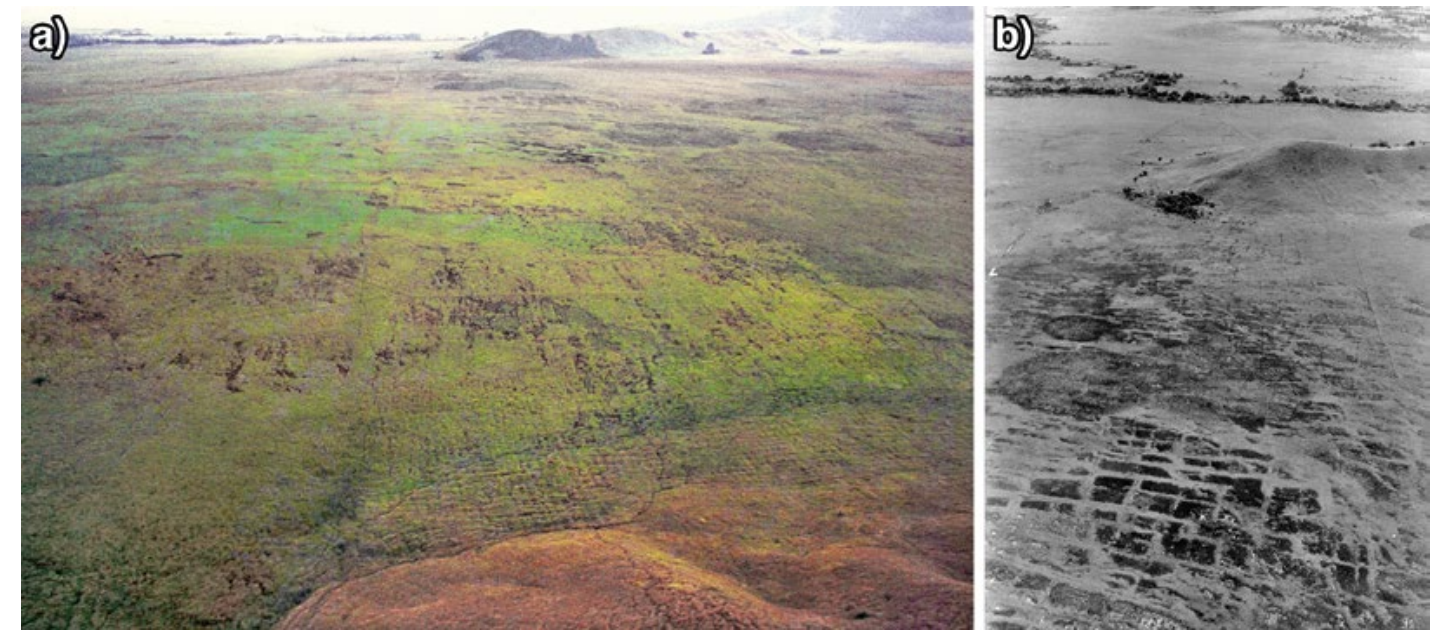

Figure 16.14 Looking across the North Wahgi Swamp between Ep Ridge and Mugumamp Ridge at fossil ditches and cultivations thought more likely to be Phase 5 than Phase 6.

a) is a wide view NE from above Ep Ridge in the foreground to Mugumamp Ridge, top centre right, and the tree-lined course of the Gumants River, top left. The first European patrol into the area in 1933 reported no signs of human presence or activity at Ep Ridge, the North Wahgi Swamp to its north or Kuk Swamp to its south (see Chapter 23). b) A closer view of one of the areas of old ditches and cultivations between Ep and the western end (cf. Fig. 12.19).

Source: Photographs by Wal Ambrose, Kuk archive, 1972. 

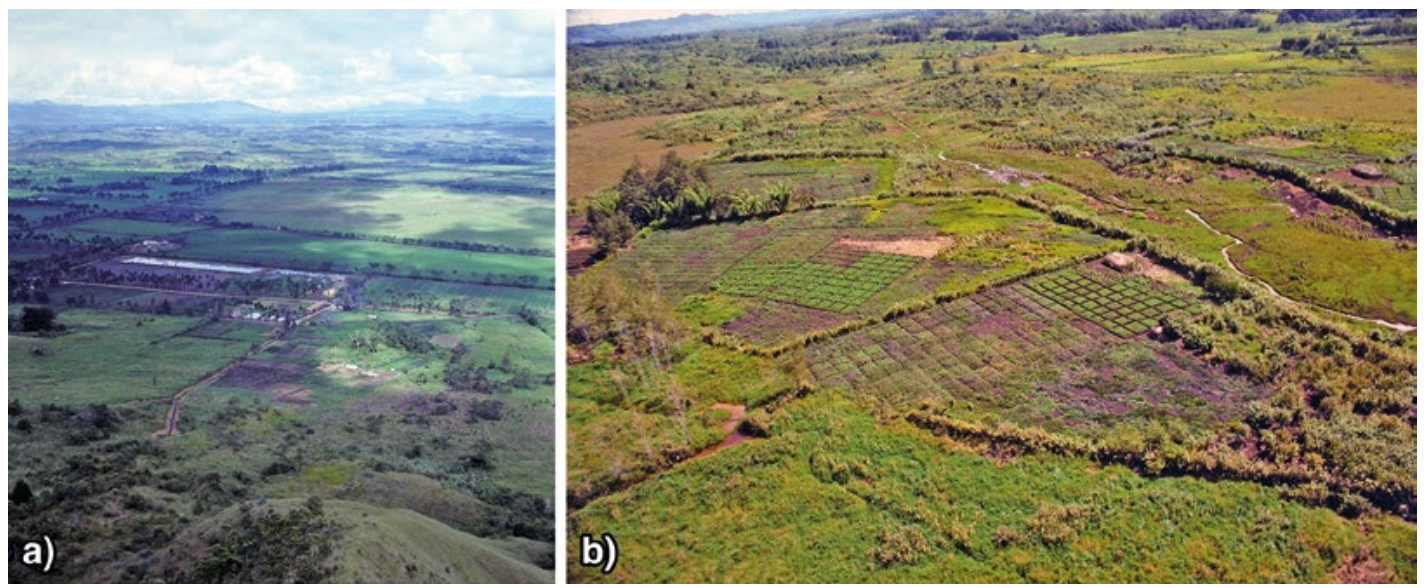

Figure 16.15 The changing distribution of upper Wahgi population. a) A view west from Ep Ridge and Baisu Corrective Institution over the upper Wahgi Valley floor.

The floor of the valley lost population in Phase 6 to what Russell Blong (1986: 288) calls the Mt Hagen volcanic apron, on which new population centres emerged. The apron edge can be recognised by the level line it forms across the picture above the irregular escarpment that separates it from the valley flats. The apron extends back from this edge to the higher country beyond. b) On the apron there is a managed landscape of grassland, shrubby regrowth and cultivation. The dispersed nature of settlement can be seen in the scattered distribution of the long round-ended women's houses and the clumps of planted bamboo and useful trees.

Source: Photograph A by Ed Harris and B by Paul Gorecki, Kuk archive, 1977.

Another history of population growth and movement following the introduction of the sweet potato is reconstructed from Engan oral histories by Polly Wiessner and Akii Tumu (1998: 4952, 55-56, 75, Appendix 2; cf. Wiessner 2005: 121, 127). They estimate a foundation population of some 10,000-20,000 about 250-300 years ago, ranging from sedentary horticulturalists in eastern Enga between 1500 and $1900 \mathrm{~m}$ altitude to scattered mobile groups above $2100 \mathrm{~m}$ in the extensive high country of western Enga, heavily dependent on hunting and gathering. The new plant was readily accepted in areas of high altitude or poor soils, but there were significant population movements overall as subsistence strategies changed to take advantage of its arrival (Wiessner 2005: 127). Today, the region is home to 150,000 Engan speakers. A similar process of population growth can be envisaged for the upper Wahgi valley, but such estimates have not yet been attempted.

\section{Conclusion}

We conclude that the large-scale abandonment of wetlands, the establishment at Kuk of women's houses adjacent to the swamp that was used for cultivation and pig grazing and the neglect at Kuk of major disposal channels were all rather immediate symptoms of the sweet potato's arrival in the Wahgi and its subsequent social and demographic effects.

Phase 6 at Kuk corresponds chronologically exactly to the period after AD 1700, when an Ipomoean Revolution has been confidently reconstructed for the highlands of New Guinea from oral histories (e.g. Ballard 1995, 2001; Wiessner and Tumu 1998; Wiessner 2002). The archaeological evidence shows that at Kuk three kinds of wetland responded differently to the suggested adoption of the sweet potato within the regional economy.

a. The southeast-northwest line of the Phase 6 water-disposal channels, Simon's and Wai's Barets, came to mark the boundary between uncultivated deeper swamp to the north and east and cultivated swamp margin and higher ground to the south and west. The abandoned 
areas were used instead for extensive pig grazing. Women's houses with stalls for pigs were established on the banks of the major disposal channels. The maintenance of these channels was somewhat neglected.

b. Swampland of intermediate elevation (e.g. A10 and 11 southwest of Simon's Baret) saw continued cultivation, possibly of the same crops as in pre-Ipomoean times; but ditch maintenance was at a lower level of labour intensity.

c. Drier swamp margins (e.g. A9) saw continued intensive cultivation, maintaining a high level of drainage density, although the individual field ditches were somewhat shallower. There is evidence for soil being moved for raised-bed cultivation. We cannot be certain about what crops were being grown, but by ethnographic analogy, sweet potato is a strong possibility.

The archaeological evidence reviewed in this chapter has not so far been supplemented by archaeobotanical evidence of the crops themselves (cf. Chapter 20, the second paragraph above 'Conclusions'). As a result, we cannot identify with certainty the moment of the sweet potato's arrival in the wetland sphere of cultivation. Even the direct proof that was once cited for its presence no longer exists, since the claimed sweet potato fragment proved to be yam (see Fig. 16.13). Nor is it possible to reach firm conclusions about landuse on the basis of ditch morphology, network hydrology and inferences from abandonment, although the evidence does point towards wetland disintensification, which is consistent with the growing success of dryland sweet potato cultivation.

What we can reconstruct from Kuk is consistent with a process of intensification in the dryland sphere based on the sweet potato and associated with big-men, large-scale pig production and more coercive gender relations. By itself, the Kuk evidence of ditches and field systems is not unambiguous. However, when combined with the local evidence in Phase 6 of women's houses with pig stalls located adjacent to grazing land, plus the abandonment of large-scale swamp drainage throughout the upper Wahgi, then a clearer picture of the Ipomoean landscape is starting to emerge.

\section{Appendix 16.1: A Final Note About the Shell Trade}

\section{Jack Golson}

Since Ian Hughes (1977) wrote his treatise on New Guinea stone age trade, there has been an intriguing discovery, of presently unknown significance, at the Yuat River, some $120 \mathrm{~km}$ upstream from where Mead and Fortune saw pearl shell being traded down to the Sepik in 1932 (see Chapter 16). At the Ritamauda rockshelter, Paul Gorecki excavated evidence of five traditionally traded marine shell species, including two fragments of gold lip pearl shell (Pinctada maxima). The finds were made in the two lowest horizons, IV and V, of a sequence of fluctuating site use that may have ceased a couple of hundred years before European contact (for the excavations Gorecki 1989: 153-155; for the shells Swadling and Anamiato 1989: 226-227).

The trade shells were scattered through the $1.35 \mathrm{~m}$ depth of Horizons IV and V, with the two pearl shell pieces in the top spits of Horizon IV (Swadling and Anamiato 1989: Table 11.1). There are problems with the chronology of these lower horizons at Ritamauda (Golson 2005: 472). However, the radiocarbon dates for the top $100 \mathrm{~mm}$ of Horizon IV and the bottom $200 \mathrm{~mm}$ of Horizon $\mathrm{III}^{1}$ give a calibrated range, at two standard deviations, of $3240-1820 \mathrm{BP}^{2}$ This suggests

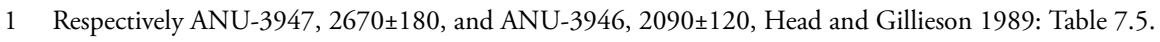

2 ANU-3947 calibrates to between 3240 and 2340 BP and ANU-3946 to between 2340 and 1820 BP, rounded off to the nearest 10 years. BP (Before Present), is AD 1950 by radiocarbon convention. 
that none of the trade shells at the site is younger than around 2000 or 3000 years, which is at the same time a reasonable estimate for the age of the two late-occurring pearl shell items. Swadling and Anamiato (1989: 226) say that these last shells would have come from slightly sickle-shaped slivers similar not only to those still worn by people in the upper Yuat as nose ornaments, and once common in the upper Wahgi, but also to pearl shell lengths strung in other ways in the Sepik lowlands and the upper Karawari.

Based on her study of the unpublished fieldnotes of Mead and Fortune on the middle Yuat in 1932, McDowell (1989: 31-32) notes of the riverine trading system by which mountain products moving downstream were exchanged for those of sea and river moving up, that there was one exception: 'the highlands shell breast ornament came down out of the highlands and went downriver in exchange for shells' (1989: 32). McDowell (1989: 33, footnote 8) says that while it is not clear what Mead meant by 'highlands shell breast ornament', it is likely to be the pearl shell crescent whose south coast provenance and importance in the upper Wahgi have been indicated in Chapter 16.

Perhaps the pearl shell at Ritamauda, though deriving from a pearl shell sliver and not a crescent, has the same ultimate provenance. Swadling (1994: 141-142) cites Landtman (1927) for the manufacture of both crescents and slivers of pearl shell at Torres Strait and their onward trade at the time of his fieldwork in the area. As yet, however, we know little of the chronology of the shell industry there. 
This text is taken from Ten Thousand Years of Cultivation at Kuk Swamp in the Highlands of Papua New Guinea, edited by Jack Golson, Tim Denham, Philip Hughes, Pamela Swadling and John Muke, published 2017 by ANU Press, The Australian National University, Canberra, Australia. 